\title{
GROTTE ANDRÁS
}

\section{KÍSÉRLET NÉHÁNY MAGYARORSZÁGI ÖTVÖSJEGY FELOLDÁSÁRA XVI.}

Korábbi közleményeim folytatásaként magángyüjteményekben és a műkereskedelemben talált új ötvösjegyeket, illetve jegyváltozatokat kívánok bemutatni, és megkísérlem ezek feloldását. A már közölt jegyek esetében most is általában Kőszeghy Elemér jegykönyvére, ${ }^{1}$ a pest-budai jegyeknél pedig P. Brestyánszky Ilona munkájára ${ }^{2}$ hivatkozom a jegy ottani folyószámával.

Pest

2009-es budapesti árverésen kelt el egy empire boroskancsó a B:123 1817-es pesti próbajegyhez hasonló, de évszám nélküli próbajeggyel és az 18171818. december 15. között használt „q" (B:204) évbetűvel. ${ }^{3}$ A mesterjegy a korábban közöletlen, ovális keretbe írt "AS" volt,

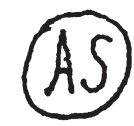

amelyet a katalógus nagyon helyesen Starzer Antal jegyeként határozott meg. Starzer Antal 1816. június 12-én lett a pesti céh tagja. ${ }^{4}$ Ez a jegy első mesterjegye lehetett, amelyet később vagy nem használt, vagy eddig ezzel jelzett tárgy még nem került elő. Többi jegyével, a B:318, B:319 jegyekkel áttekinthetetlen mennyiségű tárgy található köz- és magángyüjteményekben, és kerül elő a műkereskedelemben.

A budapesti mükereskedelemben bukkant fel egy filigrángomb 1800 körülre keltezhető, a B:118 jegyhez hasonló próbajeggyel és

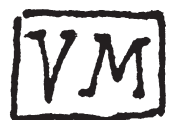

mesterjeggyel. Ugyanezzel a mesterjeggyel filigránkosárka van a Budapesti Történeti Múzeum gyüjteményében is. ${ }^{5}$ A mesterjegy Messerschmidt Vince jegye lehet, aki 1779 körül született, és 50 évesen 1829. július 2-án halt meg Pesten, a Belvárosban. Felesége, Theresia Schedl idősebb volt nála, 1830. június 29-én halt meg 59 évesen. Két fia volt: az idősebb, Franciscus Xaverius 1830. június 18-án halt meg 27 évesen (születését nem találtam meg). Másik fia 1809. augusztus 13-án született, és mindöszsze három napot élt. Két lánya közül Anna Susanna 1807. február 18-án, Elisabetha Maria pedig 1810. november 7-én született. ${ }^{6}$ Ismerjük egy inasát is: Krommer Jánost 1817. augusztus 3-án szegődtette 5 évre. ${ }^{7}$ Valószínűleg az ő jegye a keretezés nélküli „VM" jegy is, amellyel a Budapesti Történeti Múzeum mentekötöjét jelezte. ${ }^{8}$

A budapesti múkereskedelemben bukkant fel egy arany pecsétgyürü az 1860-as évekre keltezett B:185 próbajeggyel, „PEST” B:233 helybélyeggel és „WS" mesterjeggyel.

\section{WS}

A jegy a monogram alapján Schlingott Vilmos vagy Stenger Vilmos jegye lehetne. Az idősebb Schlingott az 1860-as években már valószínúleg nem dolgozott, így a jegyet, amíg ezt cáfoló újabb adat nem kerül elö, Stenger Vilmos jegyének tartom. Tőle korábban már volt egy gyürü budapesti árverésen. ${ }^{9}$ 
Ugyancsak a budapesti műkereskedelemben bukkant fel egy pecsétgyürü, szintén 1860 körülre keltezhető pesti B:185 próbajeggyel és B:233 helybélyeggel. Mesterjegye „LS” volt.

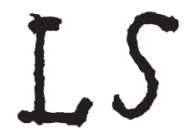

A mestere valószínűleg Segner Lipót volt, akiről ugyancsak nem rendelkezek részletesebb adatokkal. (A monogram alapján szóba jöhetne Spitzer Lipót is, de valószínű azonossága Spitzer Hermann-nal ezt talán kizárhatja. Az 1812. október 12-től a céh tagjaként müködő Stróbel Lőrincről pedig 1840 után nincs adat.) Valószínúleg Segner Lipót műve a Budapesti Történeti Múzeum LS jegyű pecsétgyűrüje is. ${ }^{10}$

Egy budapesti magángyújteményben egy lekerekített végű nyéllel készült evőkanálon a „PESTH” helybélyeg és az 1864-es B:172 próbajegy mellett érdekes és nagyon szokatlan mesterjegyet találtam.

\section{SCHICKINGER \& SOHN}

A kiírt "SCHICKINGER \& SOHN" jegy arra utal, hogy Schickinger József és egyik fia egy nálunk addig szokatlan társas vállalkozást hozott volna létre. Magyarországi ötvösök közötti hasonló vállalkozásra eddig még nem találtam adatot. Nézzük először az életrajzi adatokat. Schickinger József 1813. március 6-án született Pesten, a Belvárosban. Apja Nicolaus Schickinger cerdo (tímár) volt. 1841. szeptember 28-án kötött házasságot a Budán született Elisabetha Schönfelddel a Terézvárosban. Itt született 1842. május 7-én idősebb fia, Adolf Károly. Második fia, Ágoston 19 évesen 1871. május 27-én meghalt. ${ }^{11} \mathrm{Az}$ idősebb fiú és az apa halálának időpontját nem találtam meg, de Schickinger József 1870-ben még házassági tanú volt. ${ }^{12} \mathrm{~A}$ társas vállalkozás másik tagja valószínúleg az idősebb fiú, Schickinger Adolf lehetett. Ô 1864. július 22-én a Pesti Kereskedelmi és Iparkamara egyik iratában szerepel Zöldfa utca 5. alatti lakosként. ${ }^{13}$ A nálunk szokatlan, általam eddig nem ismert, ötvösök közötti vállalkozási forma megszokott volt a bécsi arany- és ezütmúvesek között, ami mesterjegyeikben is megjelent. A legismertebb a Stephan Mayerhofer - Carl Klinkosch-társulás, amelynek két sorban teljesen kiírt, de "M\&K" alakú jegye is ismert, és társasági formában már 1836-tól müködött, ${ }^{14}$ de említhetném a „Triesch \& Co." és „T \& Z" jegyű társaságokat is. ${ }^{15} \mathrm{~A}$ jelenség pesti megjelenése még igényel további kutatást.

\section{Óbuda}

Az 1820 és 1835 között Budaújlakon, 1838-tól Óbudán müködött Scherr (Scheer) Mátyástól eddig egy 1822-es óbudai próbajeggyel és a B:103 mesterjegygyel jelzett sókanalat ismert a kutatás, amely egykor a Kilényi-gyüjteményben volt. ${ }^{16}$ Legutóbb egy hasonló filigránkanálka bukkant fel egy budapesti magángyüjteményben Óbuda 18x9-es (a középső számjegy olvashatatlan) próbajegyével, „,B” évbetüvel és Scheer Mátyás új mesterjegyével.

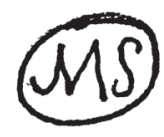

Engel Sámuelnek 1820-as próbajeggyel és pajzsba írt SE mesterjegyével jelzett, 1766-os bajor pénzérmével készült kanala egykor a Wielandgyüjteményben volt. ${ }^{17}$ Már korábban is dolgozott Óbudán, ugyanis 1920-ban 1810-es próbajeggyel jelzett gombolyagtartóját árverezték el Budapesten, ${ }^{18}$ 2005-ben pedig filigrános szűrőkanalát (teaszürő vagy porcukorhintő?) aukcionálták, amely 1820 körül, talán 1823-ban (a próbajegy nagyon kopott volt) készülhetett. ${ }^{19} \mathrm{~A}$ budapesti mükereskedelemben nemrégiben egy tejszínes kiöntő jelent meg 12-es próbajeggyel és kiírt „Engel” mesterjeggyel.
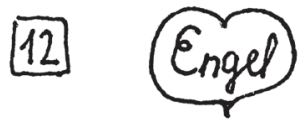

Lehet, hogy ez Engel Sámuel munkája volt? Óbudáról eddig finomsági jegyeket nem ismertünk. 2013-ban budapesti magángyűjteményben egy további finomsági jegyet is találtam egy Ádler Fülöp B:98 mesterjegyéhez hasonló jeggyel jelzett tajtékpipán. Ez a 13-as jegy is lehet, hogy óbudai.
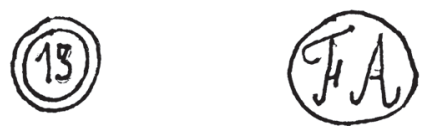

Ugyancsak 2013-ban szerepelt budapesti műkereskedelemben egy ezüst szerelékes pipa. A veretek 1838-as próbajeggyel készültek (B:93), a mesterjegy fekvő oválban „IS".

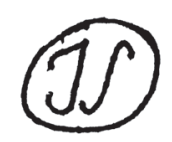

A jegy az 1828-1833 között kimutatható Seitz Izsák, Soszberger József vagy Stigler Ignác jegye le- 


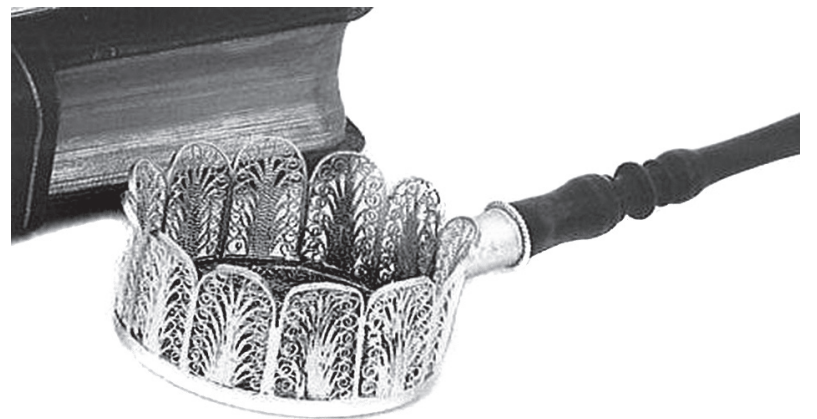

1. Engel Sámuel: Teaszürö. Óbuda, 1820 körül. Magántulajdon

het. ${ }^{20}$ Hármuk közül egyikük készíthette 1833-ban az egykor pesti magángyújteményben volt B:104 mesterjegyư cukorfogót és a Budapesti Történeti Múzeum tinta-, porzó- és tolltartóját. ${ }^{21}$ Egészen különleges az ugyancsak 1833-ban készült és B:104 mesterjegyü, négykarú kandaláberbetétekkel kiegészített gyertyatartópár, amelyet Bécsben árvereztek el 2005-ben. ${ }^{22}$ Óbudai ötvöstől még hasonlót sem láttam.

Egy budapesti magángyűjteményből két, eddig ismeretlen JD monogramú mesterjeggyel és óbudai próbajeggyel jelzett tárgy került elő. Az első mesterjegy ovális keretének hosszabb átmérője 2,5 mm volt.

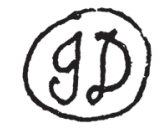

A filigránművel áttört nyelű füszerkanálon Óbuda B:85, 1820-as próbajegyének olyan változata volt, amelynél az évszám két első jegye nem a pajzs mellett, hanem a későbbi jegyekhez hasonlóan a korona mellett látható, és más a korona rajza is.

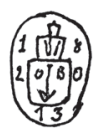

Ez a kanálka árverésről került jelenlegi tulajdonosához. ${ }^{23}$ (Egy ugyan ilyen kanálka, nyelén „18LK24" véséssel a műkereskedelemben fordult elő.) Ugyanezzel a jegykombinációval 2003-ban egy filigránmívű kosárka szerepelt árverésen. ${ }^{24}$ Mindkét tárgy mestere Jacob Drucker lehetett, aki 1850ben 54 éves volt. ${ }^{25} \mathrm{~A}$ másik JD mesterjegy ovális keretezésének hosszabb átmérője $4 \mathrm{~mm}$ volt.
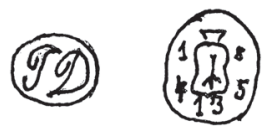

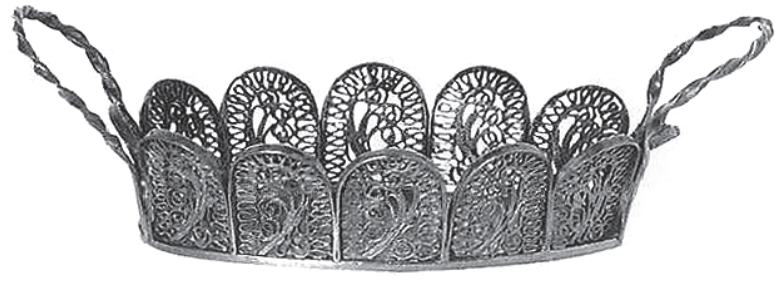

2. Jacob Drucker: Kosárka. Óbuda, 1820. Magántulajdon

Ezzel a jeggyel és Óbuda új, 1845-ös próbajegyével lapát alakú nyéllel készült evőkanál volt a már említett magángyűjteményben. Életkor alapján ez is lehet Jacob Drucker munkája, de szóba jöhet Joannes Donaberger is, aki 1843-ban kötött házasságot Óbudán. ${ }^{26} \mathrm{~A}$ JD monogramú mester készítette az 1938-as árverésen szerepelt ékszerládikát és egy 2002-ben előkerült vizitkártyatálkát is. ${ }^{27}$ Bár mindkét tárgyat az 1820-as próbajeggyel jelezték, sajnos nem tudom, hogy a két mesterjegy közül melyikkel (valószínübb, hogy a kisebbikkel).

Az egyik legtermékenyebb óbudai mester Polák József volt. Az egykor az Óbudai Zsidó Múzeum tulajdonában volt, jelenleg lappangó tórakészletén levő 1820-as próbajegy tanúsága szerint már ekkor Óbudán dolgozott. ${ }^{28} 1828$-ban a mühely egy legényt is alkalmazott. ${ }^{29}$ Mesterjegye általában ovális keretezésű JP monogram. Azonban 2006-ban a mükereskedelemben felbukkant ennek szögletes keretü változata is egy 1833-as próbajeggyel jelzett keresztelőérmen. ${ }^{30}$

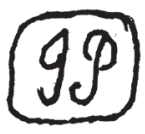

A legtöbb munkáját azonban a B:102 mesterjegygyel jelezte, legalább is a közlések ezt a meghatározást jelezték. Ezek a munkák - a már említett tórakészleten kívül -: két keresztelőérem 1825-ös és 1830 körüli próbajeggyel és egy füszerkanál 1830 körüli próbajeggyel a Budapesti Történeti Múzeumban, ${ }^{31}$ több keresztelőérem foglalata a Magyar Nemzeti Múzeumban. ${ }^{32}$ 1833-as próbajeggyel jelezték egy németországi magángyưjtemény keresztelő érmét, ${ }^{33}$ egy 1990-es árverésen felbukkant ${ }^{34}$ és egy 2005-ös árverésen szerepelt ${ }^{35}$ keresztelőérmet is. 2002-es árverésen 1835-ös próbajegyû́ keresztelőérme szerepelt. ${ }^{36} 1838$-as próbajeggyel jelezték egy 2000-es aukción ${ }^{37}$ és egy 2006-os aukción felbukkant keresztelőérmét. ${ }^{38}$ Egy 1942-es aukción felbukkant keresztelőérem ${ }^{39} 1845$-ös próbajeggyel készült.

Németországi magángyüjtemény 1840-es években készült füszertartóját kiírt "STERN” mesterjeggyel jelezték. ${ }^{40}$ Ugyanez a mesterjegye a $\mathrm{Bu}$ - 

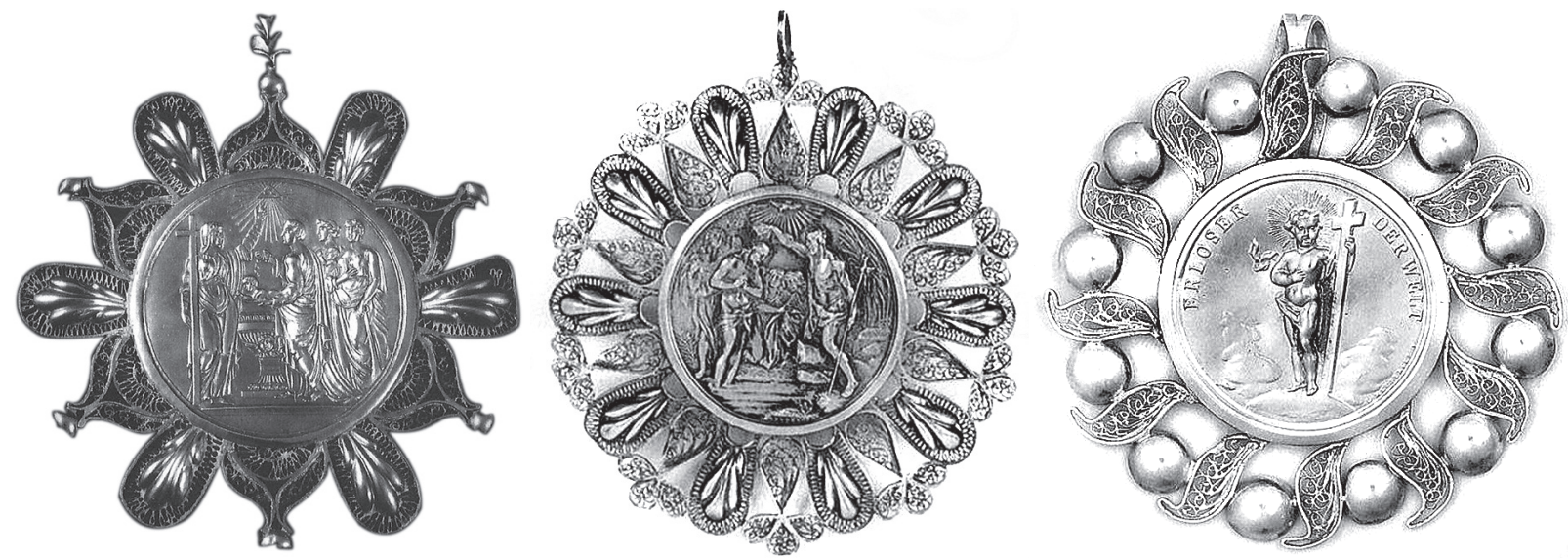

3. Polák József: Három keresztelóérem. Óbuda, 1833 és 1838. Magántulajdon

dapesti Történeti Múzeum 1845-ös próbajeggyel jelzett füszertartópárjának is. ${ }^{41}$ A mesterről eddig Óbudán semmilyen adatot nem találtam. Lehet, hogy azonos a Pesten az 1860-as években említett Stern Árminnal? ${ }^{42}$

Budapesti magángyưjteményben bukkant fel egy tajtékpipa ezüstveretekkel. A vereteken Óbuda 1825-ös próbajegye és JA mesterjegy volt.

\section{STERN}

\section{(TA)}

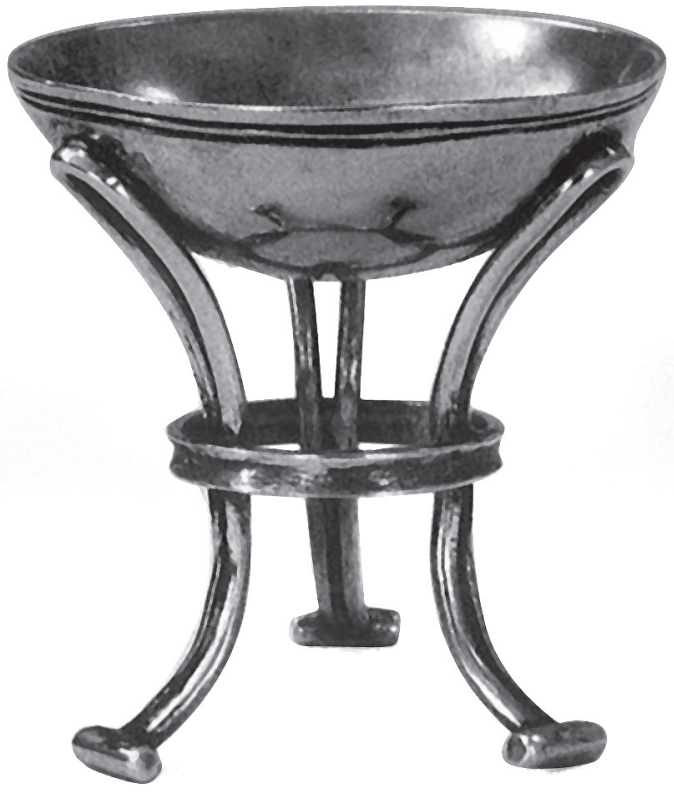

4. STERN jelzéssel: Füszertartó. Óbuda, 1840 körül. Magántulajdon
A mesterjegy Adler Józsefé lehet, aki 1828-ban működött Óbudán, de műhelyében legényt nem alkalmazott. ${ }^{43}$ Korábban ismert B:99 mesterjegyével és 1833-as próbajeggyel jelzett ezüst szerelékes tajtékpipa volt 1936-ban magántulajdonban, és 1838-as próbajeggyel jelzett ékszerládikája van a Budapesti Történeti Múzeumban. ${ }^{44} 1835$-ös próbajeggyel készültek a 2010-es árverésen szerepelt pipa szerelékei. ${ }^{45}$

\section{Kalocsa?}

$\mathrm{Az}$ internetre feltöltött gyászjelentések ${ }^{46}$ között Fekete Krisztián talált egy gyászjelentést, miszerint Kalocsán 1870. szeptember 16-án elhunyt Zöllner Ágoston aranyműves 75 éves korában. Gyászolják lánya, Triszler Károlyné Zöllner Anna, veje, Triszler

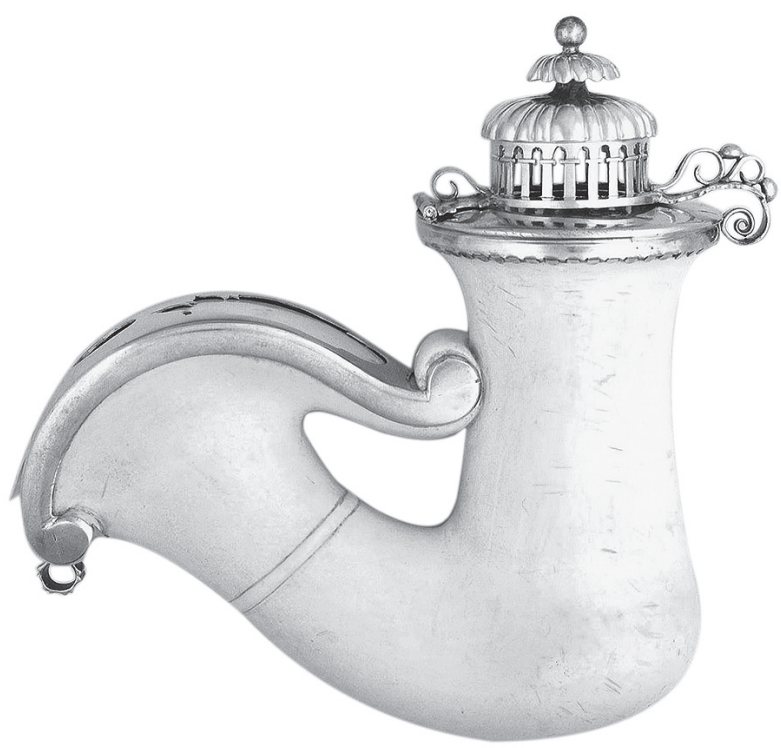

5. Ádler József: Tajtékpipa, ezüstszerelékkel. Óbuda, 1835. Magántulajdon 
Károly és unokái, Ilona és Szilárd. A kalocsai halotti anyakönyvben is megtaláltam Zöllner elhunytának bejegyzését. ${ }^{47}$ Itt sajnos a foglalkozását nem említették, de szerepelt korábban elhunyt felesége, Elisabetha Priez. Az adatokból összeállítható a szűkebb család. Kalocsa ötvöseiról semmiféle adattal nem rendelkezem, de kiindulva a város egyházi központ szerepéből, feltételezhető, hogy a városi próbajegyet valami egyházi jelkép vagy épület ábrázolásából alakíthatták ki. Ennek, valamint a ritka „AZ” monogramnak alapján átnéztem korábbi kutatásaim jegyzeteit, és találtam egy lekerekített végű nyéllel készült kávéskanalat és bütykös végü nyéllel készült evőkanalat
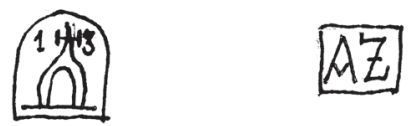

jegyekkel, valamint egy négyágú, hegyes végű nyéllel készült villát
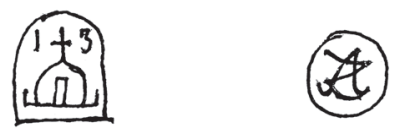

jegyekkel. Az evőkanálon és a villán egy „A" évbetü is volt. Mindhárom tárgy az 1840-es években készülhetett. Véleményem szerint a városjegyek Kalocsa városjegyei, a mesterjegyek Zöllner Ágoston mesterjegyei lehetnek.

A Magyar Nemzeti Múzeum Régiségtárába 1914-ben bekerült egy ezüstkupakkal és veretekkel készült pipa a 19. század közepéről (16/1914) jelzettel. ${ }^{48}$ A leírás szerint „tajtékpipa, rajta durván kifaragott csatajelenet, németekkel és magyarokkal. Kupakja ezüstből vert törökfőt ábrázol. Bélyegén kaputorony látható, tetején kereszttel, kétoldalt rátűzve két-két szál virág, alatta a finomságjelző 13 (Kalocsa?). Mesterjegye AZ, keret nélkül beütve."

A városjegy leírása alapján egy korábbi cikkemben Temesvárra gyanakodtam. ${ }^{49}$ Hogy nem teljesen alaptalanul, igazolja, hogy a múzeum pipagyúj-

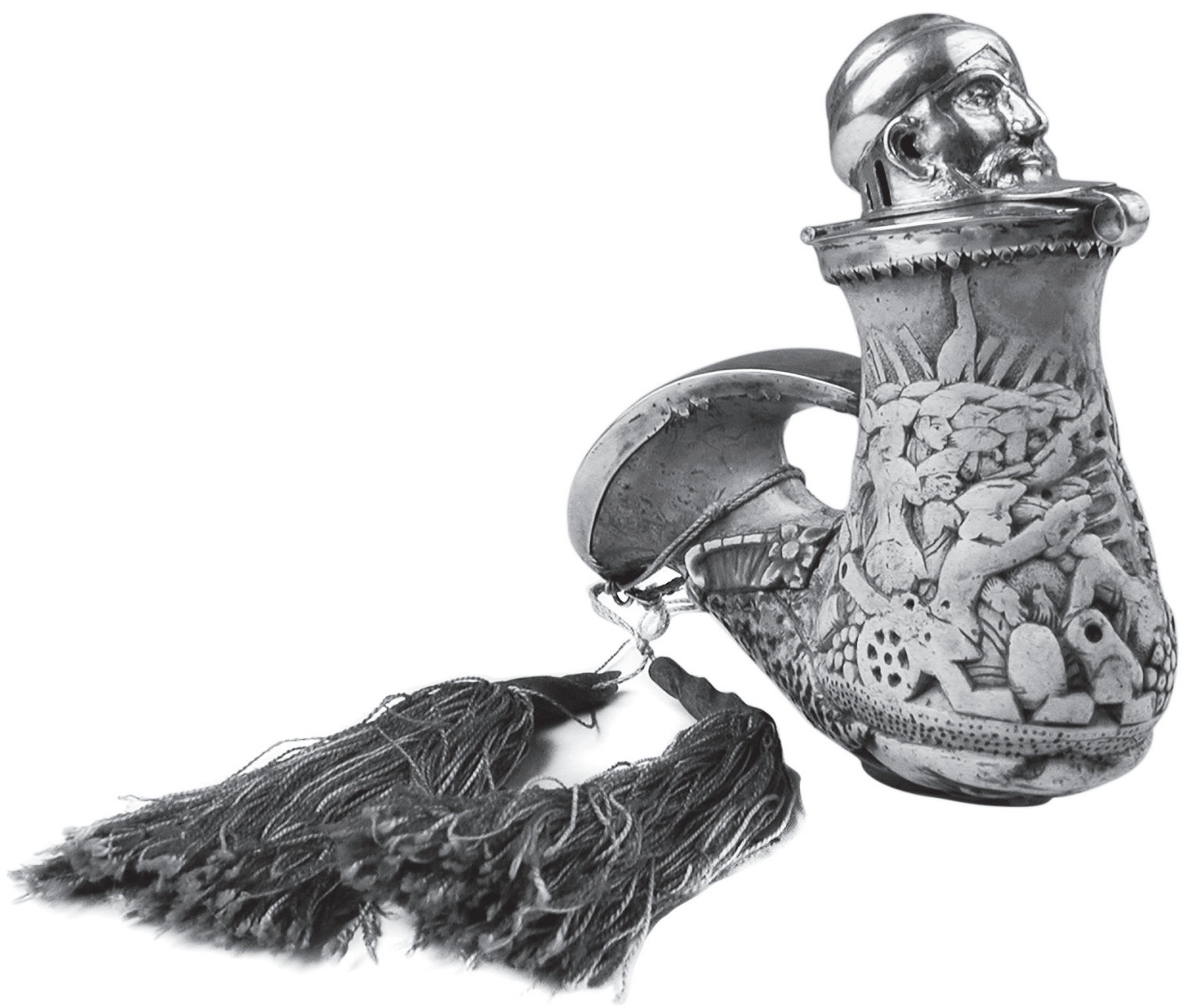

6. Zöllner Ágoston: Tajtékpipa, ezüstszerelékkel. Kalocsa, 19. század közepe. Magyar Nemzeti Múzeum 
teményének kezelője, Ridovics Anna is Temesvárt feltételezte az ezüstszerelékek készítési helyeként anélkül, hogy ismerte volna az 1916-os Közleményeket és az én cikkemet. ${ }^{50} \mathrm{~A}$ katalógusban is csak feltételesen (Temesvár?) határozta meg a pipa készítési helyét. ${ }^{51}$ Mindketten elkövettük azt a hibát, hogy a városjegy leírása, illetve képe alapján a temesvári jegyek városkapuját véltük azonosítani, holott a jegyen templom van. Nem vettük figyelembe az eredeti közlemény (Kalocsa?), valószínűleg a vétel vagy ajándékozás forrásának adatát sem. A jegyek

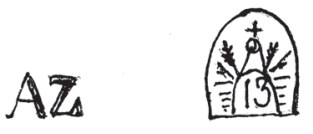

közül a városjegy - az eddigiek alapján - Kalocsa városjegyeként azonosítható, a mesterjegy valószínúleg Zöllner Ágoston mesterjegye. Teljesen biztosan azonban nem határozható meg sem a városjegy, sem a mesterjegy. Ugyanis Zöllner Ágostonról az egyetlen biztos adat a halálozási anyakönyv bejegyzése, illetve a gyászjelentés. Sem róla, sem családtagjairól nem találtam további adatokat a kalocsai anyakönyvekben. Viszont Bécsben a 19. század közepén múködött egy Johann Zöllner nevű ezüstmüves, ${ }^{52}$ és az AZ mesterjegy is felbukkant teljesen más városjeggyel három evőkanálon a Nagyházi Galéria és Aukciósház bizományos értékesítésű részlegében 2002 októberében.
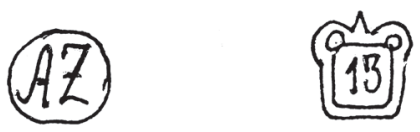

Késmárk

Az idősebb Jacobus Olmützer 1732-ben tünt fel Késmárkon, és 1760-ig említik munkásságát. ${ }^{53}$ Kőszeghy K:944 mesterjegyével és a K:933 próbajeggyel evőeszközöket ismert kassai magántulajdonból. Valószínűleg az ő munkája egy kávéskanál, melynek a merítőre felfutó nyele még 18 . századi készítést valószínűsít. A kanálon új próbajegy is volt.
A budapesti múkereskedelemben volt egy kisméretü barokk cukordoboz, ún. „szappantartó” típus a K:933 próbajeggyel, de K:949 mesterjegygyel, amit az ifjabb Jacobus Olmützerhez kapcsolt a kutatás. ${ }^{54}$ Mivel ez a cukordoboz nyilvánvalóan még 18. századi, sőt inkább a második harmadban készülhetett, mint később, valószínű, hogy a K:949 mesterjegyet már az idősebb Olmützer is használta, illetve kérdéses, hogy az ezzel a jeggyel az ifjabb Olmützernek tulajdonított tárgyak kinek a munkái. Tekintsük át az ifjabb Jacobus Olmützer munkásságát is, kit 1802 és 1828 között említenek, és közben 1826-ban céhmester is volt..$^{55}$ Kőszeghy a K:949 mesterjeggyel gyertyatartópárt ismert Farkasfalváról magántulajdonból, de 1780 körül használt K:922 próbajeggyel. Ecet- és olajtartót tállyai magántulajdonból, két gyertyatartópárt késmárki, illetve lőcsei magántulajdonból, utóbbiakat az 1800 körülre keltezhető K:923 és K:924 próbajeggyel. A K:933 próbajeggyel, amelyet már az idősebb Olmützer is használt, gyertyatartópárt ismert budapesti és evőeszközöket lő́csei magántulajdonból. ${ }^{56}$ Látható, hogy a próbajegyek alapján a két Olmützer korábban ismertetett munkái nem választhatók szét egyértelmúen. Az ifjabb Jacobus Olmützernek mesterjegyváltozata található egy kanálon K:924 próbajegy mellett a Szlovák Nemzeti Múzeumban. ${ }^{57}$

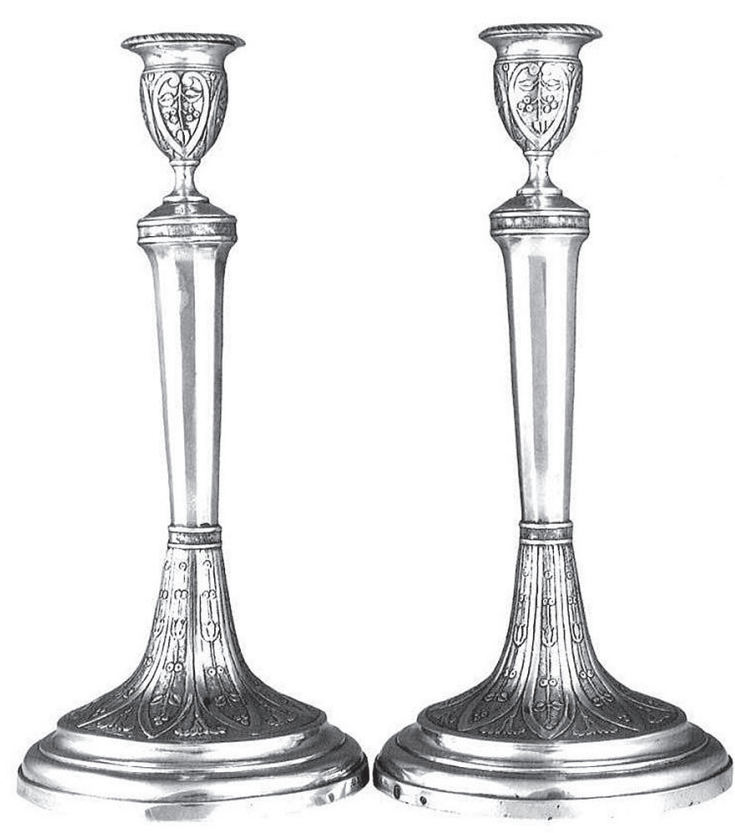

7. Jacobus Olmützer jun.: Gyertyatartópár. Késmárk, 1810 körül. Magántulajdon 


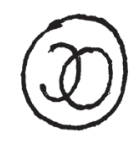

Toranová egy gyertyatartóját közölte a 19. század elejéről poprádi magántulajdonból..$^{58}$ 1927-ben az Iparmúvészeti Múzeum kiállításán szerepelt empire cukorurnája budapesti magántulajdonból..$^{59}$ Érdekes módon az árveréseken egyértelműen az ifjabb Jacobus Olmützernek tulajdonítható tárgyak fordulnak elö, így egy 1810 körül készült empire gyertyatartópár, ${ }^{60}$ mely kétszer is szerepelt árverésen, akárcsak a fedeles talpas cukortartó, szintén a század elejéről. ${ }^{61}$ Egy fedeles cukortartó, körte alakú fogóval a fedelén ${ }^{62}$ és egy empire boroskanna ${ }^{63}$ az előbbiekhez hasonlóan budapesti árveréseken került eladásra, míg egy kávéskanna és tejkiöntö ${ }^{64}$ Londonban. Budapesti magángyüjteményben találtam az ifjabb Olmützer K:923 próbajegyü és K:949 mesterjegyü villáját, melyen új évbetü, „E” volt.

A Dorotheum 2011. májusi árverésén Késmárk 1780 körülre keltezhető új próbajegye mellett egy új mesterjeggyel jelzett cukortartót árvereztek el. ${ }^{65}$
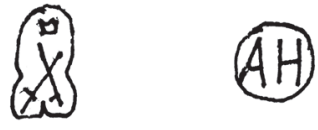

Ugyanez a mesterjegy a BÁV 2011. novemberi árverésén is felbukkant egy barokk gyertyatartón. Ezen is új próbajegy volt. ${ }^{66}$

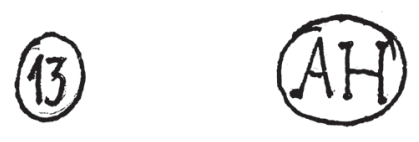

Mindkét tárgy a mesterjegy és a próbajegyek szerint az idősebb Hanzely András munkája lehetett.

A két Hanzely András, apa és fia, a 18. század közepe és a 19. század közepe között dolgozott Késmárkon. Az idősebb Hanzely András 1742-ben született, mesterként említik 1772 és halála 1816 között. Az ifjabb Hanzely András 1780-ban született, többször említik 1802 és 1828 között. 1847-ben halt meg. ${ }^{67}$ Munkásságuk a mesterjegyek és próbajegyek alapján nem, csak esetleg a tárgyak stílusa alapján választható szét. Kőszeghy az idősebb Andreas Hanzely munkájának tartja a K:946 mesterjeggyel készült evőeszközöket és egy kávés- és tejszínes kannát különböző lőcsei magántulajdonból, illetve a K:947 mesterjeggyel, fafüllel készült kávéskannát ugyancsak lőcsei magántulajdonból. A K:948 mesterjeggyel készült tárgyakat is az idősebb Hanzelynek tulajdonítja, de megjegyzi, hogy ezeket akár az ifjabb mester is készíthette. Ezek:

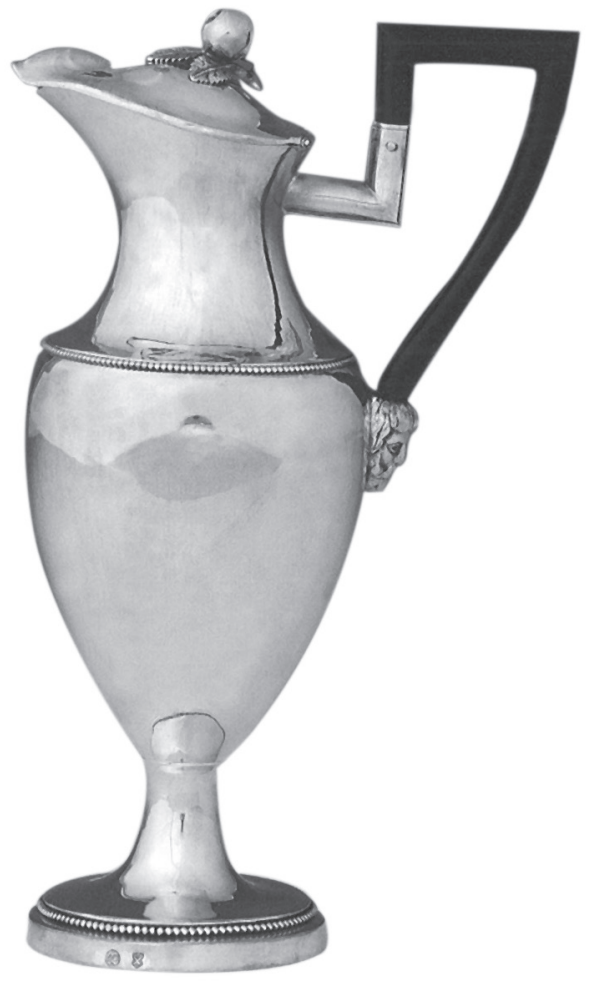

8. Jacobus Olmützer jun.: Kávéskanna. Késmárk, 1810 körül. Magántulajdon

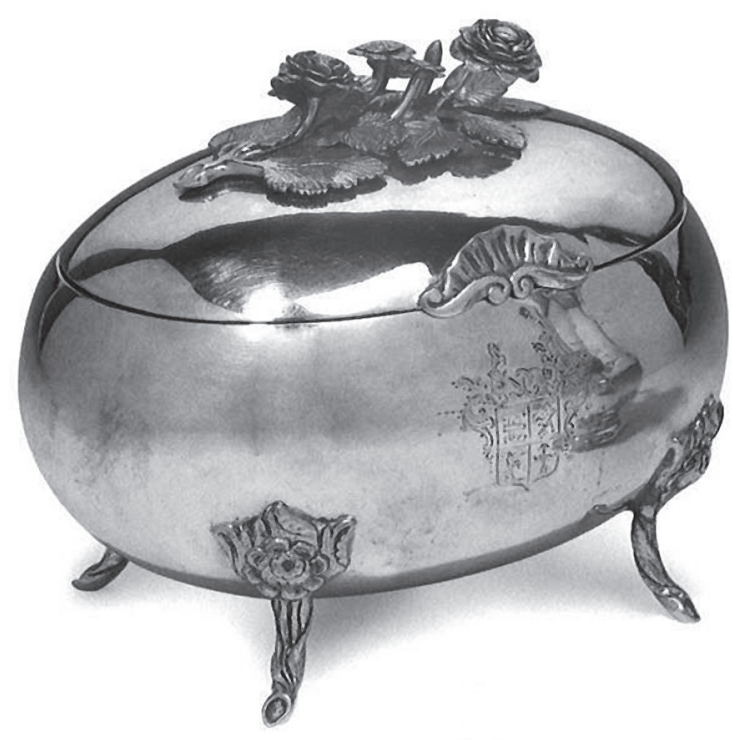

9. Andreas Hanzely sen.: Cukortartó. Késmárk, 1780 körül. Magántulajdon

késbakok akantuszlábakon selmecbányai, egy fanyelü lábas, egy fedelén bogyóval díszített lábas és két sótartó késmárki és két gyertyatartó tállyai magántulajdonban. A tárgyakon a K:922, 923, 924 


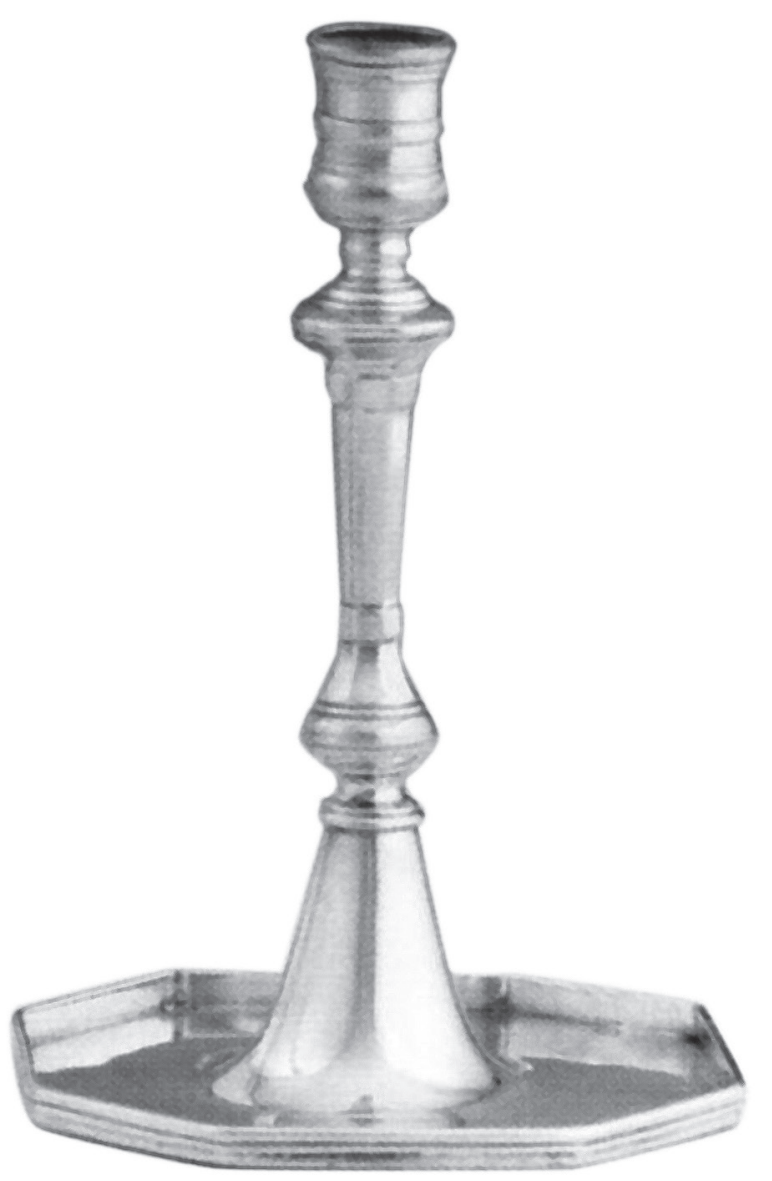

10. Andreas Hanzely sen.: Gyertyatartó. Késmárk 1760 körül. Magántulajdon

próbajegyek voltak. A késmárki plébániatemplom feszületének javításakor 1730-ban is K:948 mesterjegyet és K:924 próbajegyet használt a mester. Az alsólánci magántulajdonban levő gyertyatartókon a K:948 mesterjegy mellett csak "13” finomsági jegyet (K:934) használt. ${ }^{68}$ A Szlovák Nemzeti Múzeum cukortartóján is a K:948 mesterjegy és 1780 körülre keltezhető K:922 próbajegy van. Stílusa alapján azonban a 19. század első felében születhetett. ${ }^{69}$ Ugyancsak a stílusa alapján lehet az idősebb Andreas Hanzely munkája egy cukorszelence, ami egy svájci árverésen bukkant fel 1970-ben. ${ }^{70}$ Valószínúleg az ifjabbik mester készíthette azt a nagyon érdekes tárgyat, mely egy másik svájci árverésen került eladásra, és ma egy New York-i magángyüjteményben van. ${ }^{71}$ A 17. századi ananászserlegek mintájára készült serleg a korai historizmus megjelenésének tekinthetö. ${ }^{72}$ Stílusa alapján ugyancsak az ifjabb mester készíthette azt a tejszínkiöntőt, mely egy budapesti árverésen bukkant fel 2009-ben. ${ }^{73}$ Valószínúleg az ifjabb Andreas Hanzely munkája egy

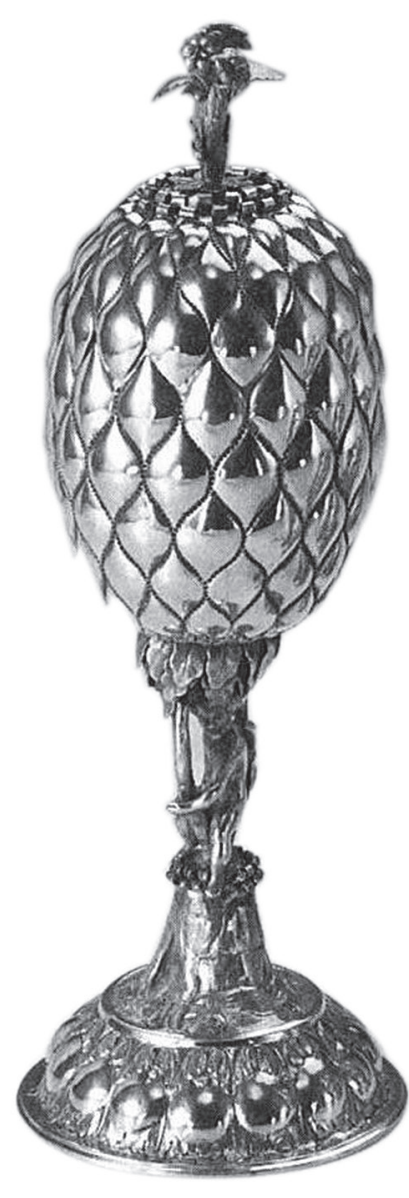

11. Andreas Hanzely jun.: Ananászserleg. Késmárk, 1800 körül. Magántulajdon

Bezerédy-címerrel díszített tányér egy németországi magángyüjteményben. ${ }^{74}$

$\mathrm{Az}$ 1828-ban említett Constantinus Michelről írtam korábban, ${ }^{75}$ az akkor írtakat egyrészt kiegészítem azzal, hogy Toranová már idézett cikkében közölt két kanalat is poprádi magántulajdonból, melyek egyike éremmel készült. ${ }^{76}$ Másrészt felbukkant a budapesti mükereskedelemben Michel egy további munkája, egy gyertyatartópár, melyen 13as finomsági jegy és a K:951 mesterjegy újabb változata volt.

$$
\text { CM }
$$

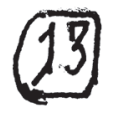

Joannes Gemzáról is írtam már egy-egy újabb mesterjegyváltozat felbukkanása alkalmából, ${ }^{77}$ így munkáinak felsorolása nem szükséges, bár megjegyzem, hogy a mester tárgyai gyakori szereplők a mükereskedelemben, árveréseken és magángyüj- 


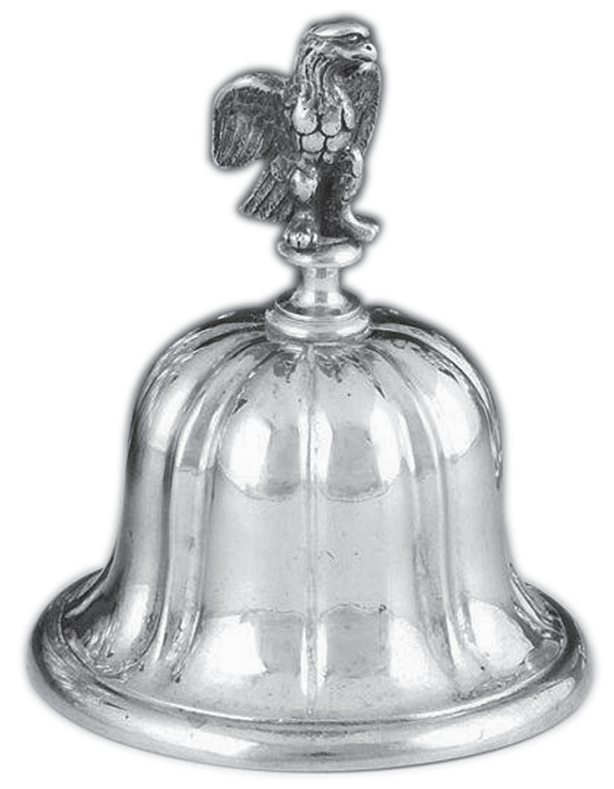

12. Johannes Gemza: Asztali csengó. Késmárk, 1800 körül. Magántulajdon

teményekben is. Legutóbb egy budapesti árverésen került elő asztali csengője 12-es finomsági jeggyel és kisméretü körbe írt „JG" betüs mesterjeggyel. ${ }^{78}$

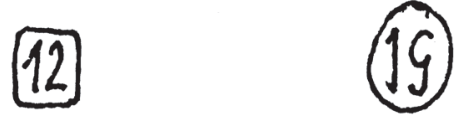

Nagyon hasonló, de szokásos méretű mesterjeggyel és K:926, a 19. század első felére keltezhető próbajeggyel találtam egy háromágú villát budapesti magángyüjteményben.

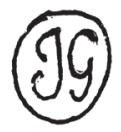

\section{Kolozsvár}

Budapesti magángyüjteményben láttam 2011-ben tíz, a 18. század modorában készült zománcos gombot. A gombokon az 1872 utáni agárfejes fémjelzés volt a kolozsvári fémjelző hivatal U betüs jelével. Mesterjegyük beütött „SJ” volt.

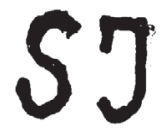

A jegy Sárga János jegye lehet, akiről korábban részletesen írtam. ${ }^{79} \mathrm{Az}$ ő munkáihoz tartozott egy késpenge is, melyen két angyal által tartott magyar címer alatt vésett felirat volt:

\section{SÁRGA JÁNOS ÉKSZERÉSZ \\ CS. ÉS KIR. UDV. SZÁLLÍTÓ \\ BUDAPEST-KOLOZSVÁR}

A kés ezüstrészét sajnos beolvasztották.

\section{Nagybánya}

2007-ben egy tűzaranyozott misekelyhet árvereztek el Budapesten, amelyet a talpperemére ütött latin nyelvű felirat szerint a Szent Rozália-kápolna részére ajándékozott 1780-ban Paulkovics József nagybányai szenátor és felesége Koffler Erzsébet. ${ }^{80} \mathrm{~A}$ kehely jelzése:
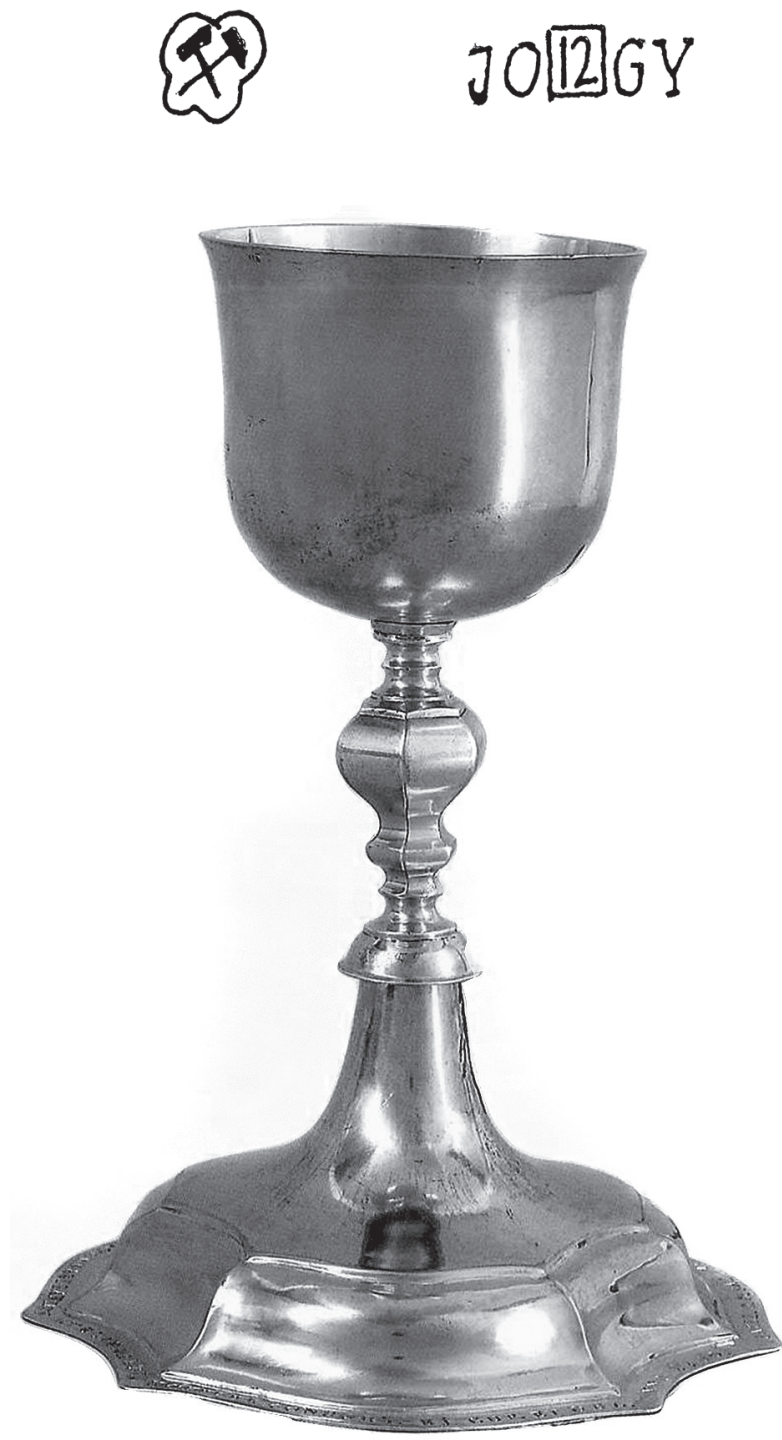

13. Gyulay József: Kehely. Nagybánya, 1780. Magántulajdon 
A nagybányai ötvösökről részletes névsorral csak a céh fennállásáig, a 17. század végéig rendelkezünk. ${ }^{81}$ Ettől az időtől kezdve összeírások szórványos adataiból kísérelhetjük meg a jegyek feloldását. A 18. század végén egységes magyarországi fémjelzés bevezetésére születtek tervek, és ezek előkészítése során összeírták az itt dolgozó ötvösöket. Az 1788-as összeírás szerint hat ötvös dolgozott Nagybányán: Enyedy János, György András, Huszár József, Gyulay József, Szabó Eötvös József és Jeremiás József. ${ }^{82}$ Közülük a fenti mesterjegy tu-

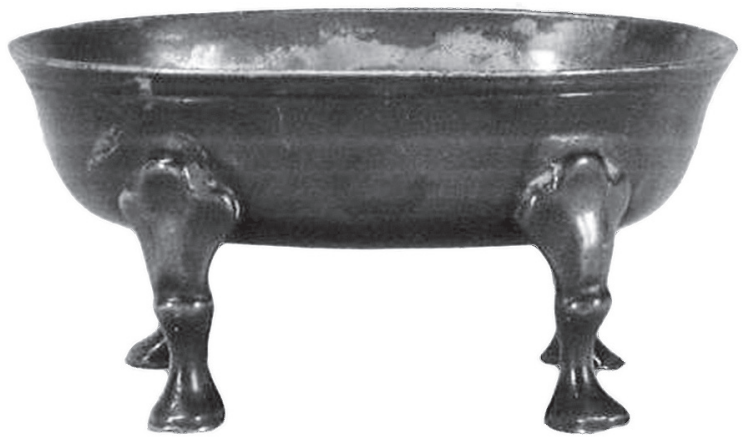

14. Huszár József: Füszertartó. Nagybánya, 1800 körül(?). Magántulajdon

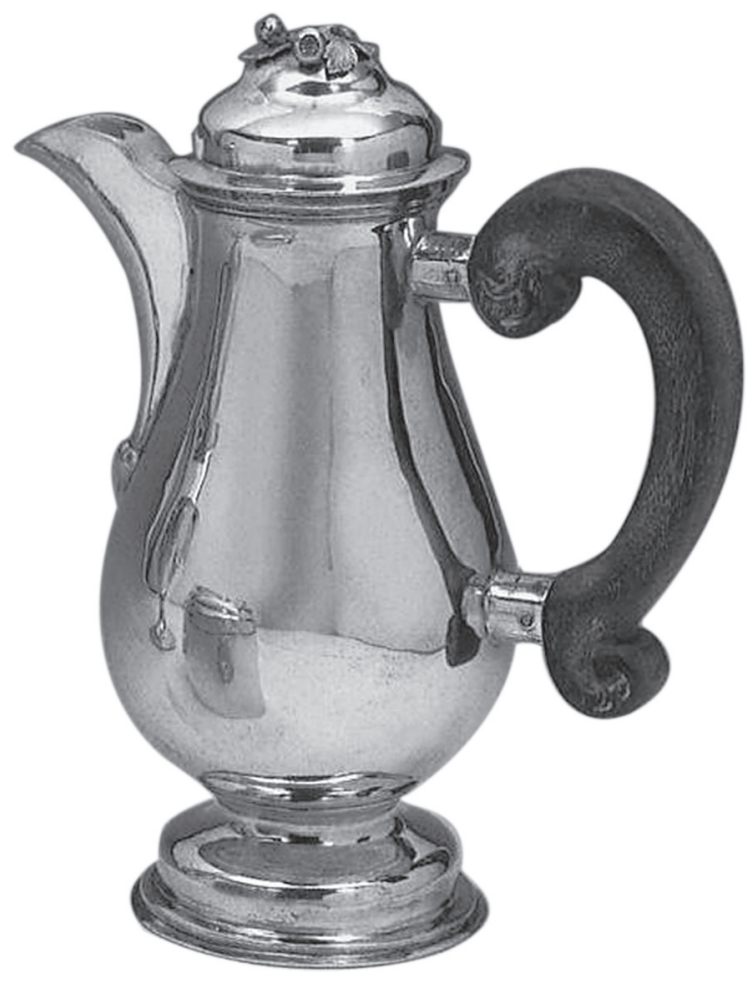

15. Huszár József: Kávéskanna. Nagybánya, 1780 körül. Magántulajdon lajdonosa Gyulay József lehetett. Talán ő lehetett a $\mathrm{K}: 1267$ mesterjegy tulajdonosa is.

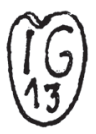

Ezzel a jeggyel 1772-ben készült ostyatányér volt a magyarberkeszi és 1779-ben készült ostyatányér a magyarláposi református egyház birtokában. ${ }^{83}$ Ugyanezzel a K:1267 jeggyel cukortartót árvereztek el Genfben 1985-ben. ${ }^{84}$ A két jegy különbségét talán az magyarázza, hogy az egyik a 13-as, a másik a 12es finomságú ezüstöt jelzi.

Ez a névsor egy további ötvös azonosítását, jegyének feloldását is lehetővé teszi.

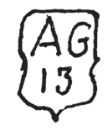

E K:1268 mesterjeggyel egykor cukortartó volt magántulajdonban. ${ }^{85} \mathrm{~A}$ jegy György András mesterjegye lehet.

Az idézett névsorban szerepelt Huszár József is, akinek jegyét Kőszeghy nem ismerte, csak nevét egy 16. századi tárgyon végzett javítás megörökítésében 1817-ben. Huszár jegye nagyon hasonló a bemutatott K:1267, 1268 jegyekhez.

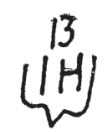

A jegyet először egy 2005-ben aukcionált, négy öntött lábon álló ovális sótartón láttam, ${ }^{86}$ melyet 2007-ben újra elárvereztek. ${ }^{87}$ 2009-ben Dorotheum árverésen szerepelt klasszicista kávéskannája. ${ }^{88}$ Legújabban egy a merítőre gyémántmetszéssel felfutó nyéllel, a 18. század végén készült kávéskanál került elő ezzel a jeggyel.

A sótartó próbajegye
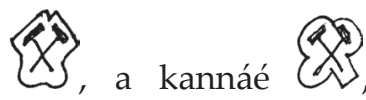

a kanálé

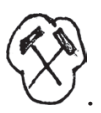

Huszár József egy újabb mesterjegye került elő a református egyház tárgyainak katalogizálása során.
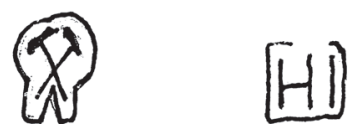
A jegy a bilkei református egyház 1799-es feliratú kenyérosztó tálján található ${ }^{89}$ A forgolányi református egyház kelyhéről $1^{90}$ a tárgyak későbbi feldolgozása során feltételezték, hogy az is Huszár munkája lenne, ${ }^{91}$ de azon csak nagybányai városjegy van, mesterjegy nincs, így a feltételezés, amíg más adat nem kerül elő, nem igazolható.

2006-ban egy 1780 körülre keltezett kávéskanna került árverésre a Dorotheumban. ${ }^{92}$

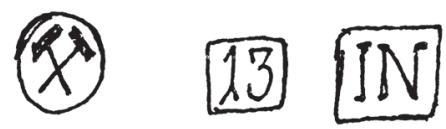

Az olvasás irányától függően IN vagy NI mesterjegy nem oldható fel a már idézett névsor segítségével, pedig ha a kanna keltezése helyes, a mesternek szerepelnie kellett volna abban az összeírásban. Szerintem azonban a kanna későbbi, de a feloldást ez sem teszi lehetővé. A 19. század elején ugyanis három ötvös is dolgozott Nagybányán, aki használhatta ezt a jegyet: Nagy Ajtay István 1813-ban, Neszner János 1814-ben és Nézner Imre 1828-ban. ${ }^{93}$

Több olyan, valószínúleg Nagybányán készült tárgy is előkerült, amelyek mesterjegye nem oldható fel a rendelkezésemre álló források segítségével. A későbbi kutatások támogatására ezeket is közzéteszem.

A már fent idézett 1985-ös genfi árverésen egy 1665 körülre keltezett, valószínűleg Nagybányán készült csemegéstálka is szerepelt. Mesterjegye "AW" volt. ${ }^{94}$ Rajzával sajnos nem rendelkezem, de 2007ben budapesti magángyüjteményben találtam egy csemegéstálkát, valószínúleg ugyanattól a mestertől.
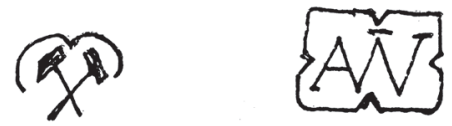

Biztosan nem azonos a két tálka, a genfinek virágok, a pestinek páva volt a tükrében. A monogramnak megfelelő mestert a céh névsorában nem sikerült azonosítanom.

2002 májusában a Dorotheumban árvereztek el egy valószínűleg szintén Nagybányán készült empire dohányszelencét. A 19. század elejére keltezett szelencén „EW" mesterjegy volt. ${ }^{95}$ Sajnos a jegyet akkor nem rajzoltam le, remélem, felbukkan még egyszer, és talán feloldható lesz.

\section{Nagyvárad}

1993-ban budapesti árverésen szerepelt egy sótartó, melynek dísze a szárára csavarodó, koronából ki-

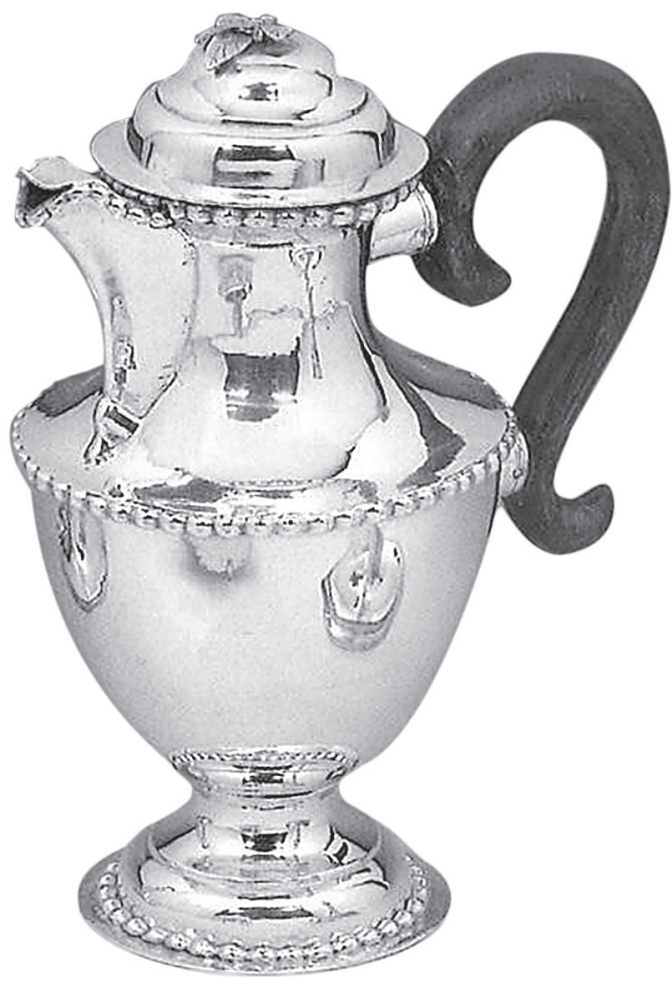

16. IN mester: Kávéskanna.

Nagybánya, 1780 körül. Magántulajdon

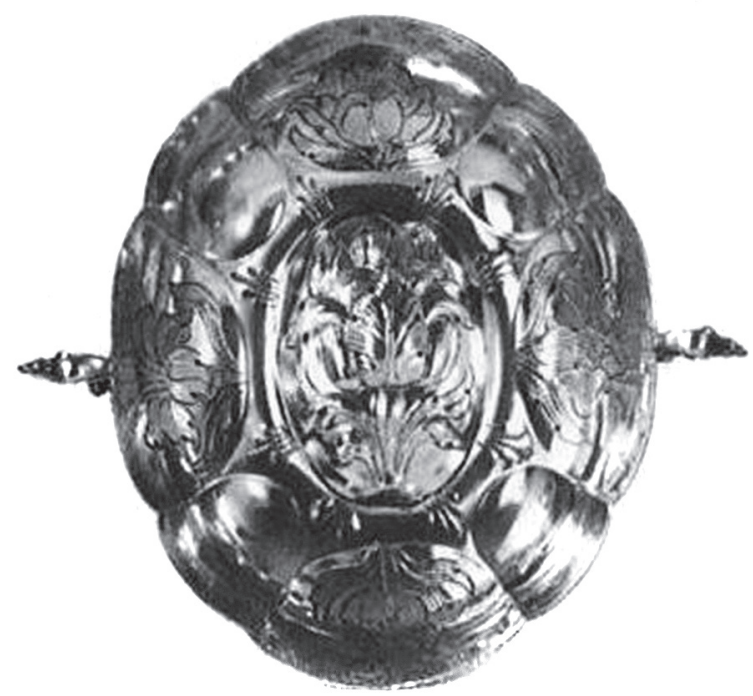

17. AW mester: Csemegéstálka.

Nagybánya, 17. század közepe. Magántulajdon

növő kígyó volt. ${ }^{96}$ A nagyváradi próbajegyű tárgy mesterjegyét tévesen olvasták Leopold Ausländer jegyének. A félig kopott jegy olvasata iránytól függően "SL" vagy "JS" lehetett csak. A sótartó 1994 márciusában a Polgár Régiségboltban bukkant fel újra. 1997ben egy budapesti magángyüjteményben megtalál- 
tam a sótartó párdarabját jól olvasható mesterjeggyel és 1820 körülre keltezhető nagyváradi próbajeggyel.

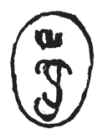

Ugyanebben a gyűjteményben ugyanettől a mestertől négy lábon álló, ovális, fedeles cukordoboz is volt. A mester egy másik müve, egy nagyméretű cukorszóró 2001 júniusában a Csók Galériában volt, majd 2002-ben Budapesten árverésre került. ${ }^{97}$ Újabban egy másik magángyüjtemény bütykös végü nyéllel készült kávéskanalán találkoztam a mesterjeggyel. Ez a jegy valószínúleg az 1828-as összeírásban szerepelt Stanczel József jegye lehet, ${ }^{98}$ aki legény nélkül dolgozott Nagyváradon. ${ }^{99}$

Pápa

Előző közleményemben sajnálatos hiba folytán, amit a korrektúra során nem vettem észre, Anton Kopf mesterjegyei hibásan - a két mesterjegy azonos rajzolattal - jelentek meg. ${ }^{100}$ Ezt a két jegyet ezért most újra közlöm:
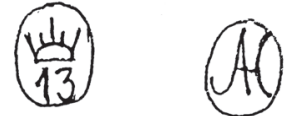

illetve

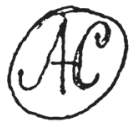

Egy budapesti magángyűjtemény keresztelőérmén Pápa csonka, a K:1593 próbajegyhez hasonló próbajegye és Jenkó Károly új mesterjegye volt.

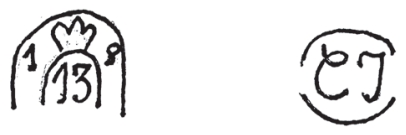

Jenkó Károlyról írtam korábban, ${ }^{101}$ mesterjegyét is közöltem. ${ }^{102}$

Pécs

Ganzer Ágoston életrajzi adatait egy korábbi tanulmányomban már tisztáztam, ${ }^{103}$ de munkáiról ekkor még a mesterjegy hiányában semmiféle adattal nem rendelkeztem. Nem sokkal később előkerültek az ellene folyt csődeljárás iratai, amelyből rekonstruálható volt Ganzer tárgyi világa, mikrokörnyezete is. ${ }^{104}$ Ebből képet alkothatunk a műhelyéről, felszereléséről, a benne készült tárgyakról, melyek leírása megtalálható az árverés leltáraiban. Konkrétan magánkézben vagy műkereskedelemben felbukkanó tárgy így még nem kapcsolható Ganzer Ágostonhoz. Ehhez szükség van a mesterjegyére is. Egyik lehetséges mesterjegyét, a kiírt „A. Gantzer” jegyet már 1999-ben sikerült meghatározni egy vidéki mükereskedésben felbukkant cibóriumról. ${ }^{105} \mathrm{Ez}$ a jegy már korábban is szerepelt egy sótartópáron egy 1997-es árverésen, de nagyon kopott volt. Előkerült egy kiírt "Gantzer" jegy is egy levesmerőn, szintén budapesti árverésen, ${ }^{106}$ de erről nem lehetett eldönteni, hogy Ganzer Ágoston vagy Ganzer János jegye volt-e. Legújabban Pécs K:1615 próbajegyéhez hasonló próbajegy mellett új jegye került elő egy budapesti magángyưjtemény hegyes végü nyéllel készült kávéskanaláról.

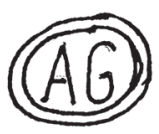

\section{Pozsony}

2014-ben budapesti árverésen szerepelt egy belül aranyozott, kétfelé osztott, ovális, fedeles szelence, funkcióját tekintve valószínűleg úti füszertartó. ${ }^{107}$ Bár a próbajegy utolsó számjegye olvashatatlan, a szelence az 1850-es évek második felében készülhetett a beütött - Kőszeghynél nem szereplő - „F" évbetű alapján. A mesterjegy „AS” volt.

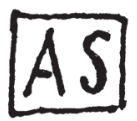

A készítő valószínűleg Scala (Skala) Ágoston, akinek kiírt SKALA mesterjegyével Kőszeghy evőeszközöket ismert pozsonyi magántulajdonból. ${ }^{108}$ August Scala 1837-ben kérte felvételét a pozsonyi céhbe, majd a remekrajz elkészítése és a mesterremekek - egy ékköves diadém és egy arany karperec - elkészítése után 1839-ben lett a céh tagja. Három inasáról is tudunk. ${ }^{109}$ Mihalik és nyomában Kőszeghy és Toranová ${ }^{110}$ csak 1850 -ig ismerte tevékenységét, azonban a most közölt szelence szerint az 1850-es évek második felében is még dolgozott. 
Budapesti magángyűjteményben találtam egy füszerkanalat, amelyet V. Ferdinánd 1848-as KB verdejegyü 20 krajcáros érméből készítettek. Mestere Paray Károly volt K:1804 mesterjeggyel. Próbajegye 1855-ös évszámú volt, ezt korábban négy olyan kávéskanálról közöltem, melyeken „E” évbetü is volt. ${ }^{111}$ A füszerkanálra azonban fordított „,G” alakú évbetüt ütöttek.

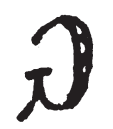

Ebből következően valószínű, hogy Scala fenti szelencéjén az olvashatatlan próbajegy szintén 1855-ös évszámú lehetett.

Bécsi árverésen bukkant fel egy cukorurna, az idősebb Josephus Gerick munkája K:1764 mesterjeggyel és 1803-as próbajeggyel. ${ }^{112} \mathrm{Az}$ évbetű " $\mathrm{H}^{\prime}$ volt, amiből jól látszik, hogy az évbetűket év közben változtatták. Joseph Gericknek egy új, sajnos nagyon kopott mesterjegye is felbukkant 1814-es próbajeggyel és „M” évbetűvel (K:1661, 1717) egy hegyes végü nyéllel készült kávéskanálon magángyüjteményben.
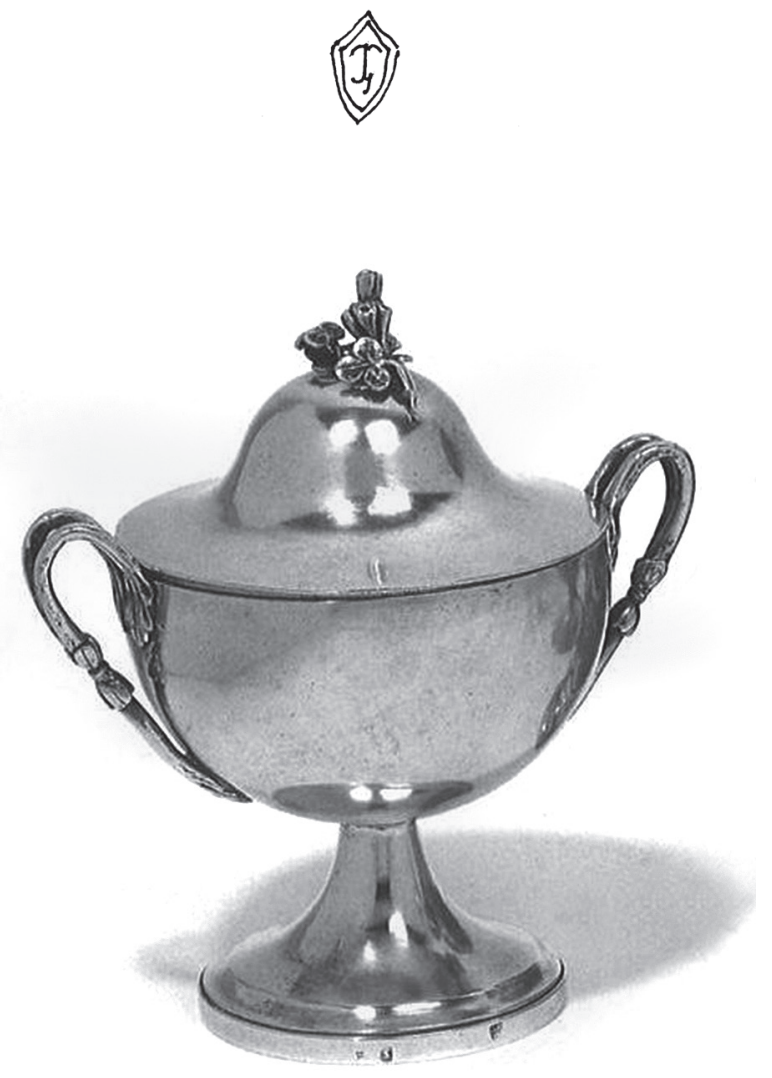

18. Josephus Gerick sen.: Cukorurna. Pozsony, 1803. Magántulajdon
Pozsony vagy Pozsony-Vártelek?

Budapesti árverésen kelt el legutóbb egy kávéskanna. ${ }^{113}$ Jelzései:

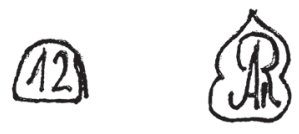

A monogram kialakítása Adam Renner K:1784 mesterjegyére hasonlít, de ennek különböző, kisebb eltérésekkel készült, más keretezésű változatait korábban már közöltem. Legjobban hasonlít egy 1841-es pozsonyi próbajeggyel ellátott kanál ovális keretbe írt mesterjegyének monogramja, ${ }^{114}$ de jó analógia egy 1819-ben, szintén Pozsonyban készült evőkanál pajzsba írt jegye is. ${ }^{115}$ Bár ezeket a jegyeket Renner már pozsonyi mesterként használta, a próbajegy miatt nem lehetünk ebben teljesen biztosak. Pozsonyból ismerünk 12-es próbajegyet, de csak egyetlen tárgyról, Joannes Christophorus Stieger 1776-ban készült fali gyertyatartójáról; ${ }^{116} 13-$ as próbajegyet is csak egyetlen tárgyról, a Szlovák Nemzeti Múzeum miniatűrjének ezüstkeretéről. ${ }^{117}$ Pozsony-Vártelekről eddig még nem került elő finomsági jegy. Ezért valószínü, hogy a címben feltett kérdésre Pozsony a válasz legalább addig, míg új adat nem kerül elő.

\section{Pozsony-Vártelek}

Budapesti árverésen bukkant fel az idősebb Fridericus Becker empire boroskannája. ${ }^{118}$ Az 1813ban (K:1817) készült kanna mesterjegye Becker K:1853 mesterjegyének kissé eltérő változata volt.

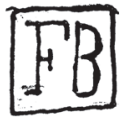

Ezt a jelzést már korábban is láttam egy két füllel készült, hatkaréjos tálkán egy budapesti magángyưjteményben, ugyancsak 1813-as próbajeggyel.

Fridericus Becker műve 1820-ból (K:1820 próbajegy) egy budapesti magángyüjtemény két kisméretű $(5,8$ illetve $6,5 \mathrm{~cm})$, oldalán vésett dísszel ékes pohara, melyek érdekessége a különös formájú „ $\mathrm{A}^{\prime}$ évbetü.

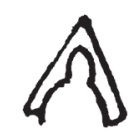




\section{Selmecbánya}

Joannes Stanga 1827-ben szabadult fel, és 1835 körül lett mester a selmecbányai ötvöscéhben. ${ }^{119}$ K:1972 mesterjegyével öt gyümölcskés van K:1945 próbajeggyel a Magyar Nemzeti Múzeumban ${ }^{120}$ és K:1946 próbajeggyel egy kávéskanál volt zólyomi magántulajdonban. ${ }^{121}$ A mesterjegy lekerekített végű téglalapba írt változatát Evá Toranová közölte a bélabányai r. k. templom kelyhéről, amely egy 18 . századi kehely másolata. ${ }^{122}$ Jegyei:

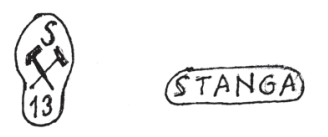

Ugyanezzel a mesterjeggyel és K:1945 próbajeggyel budapesti magángyújteményből is ismerek

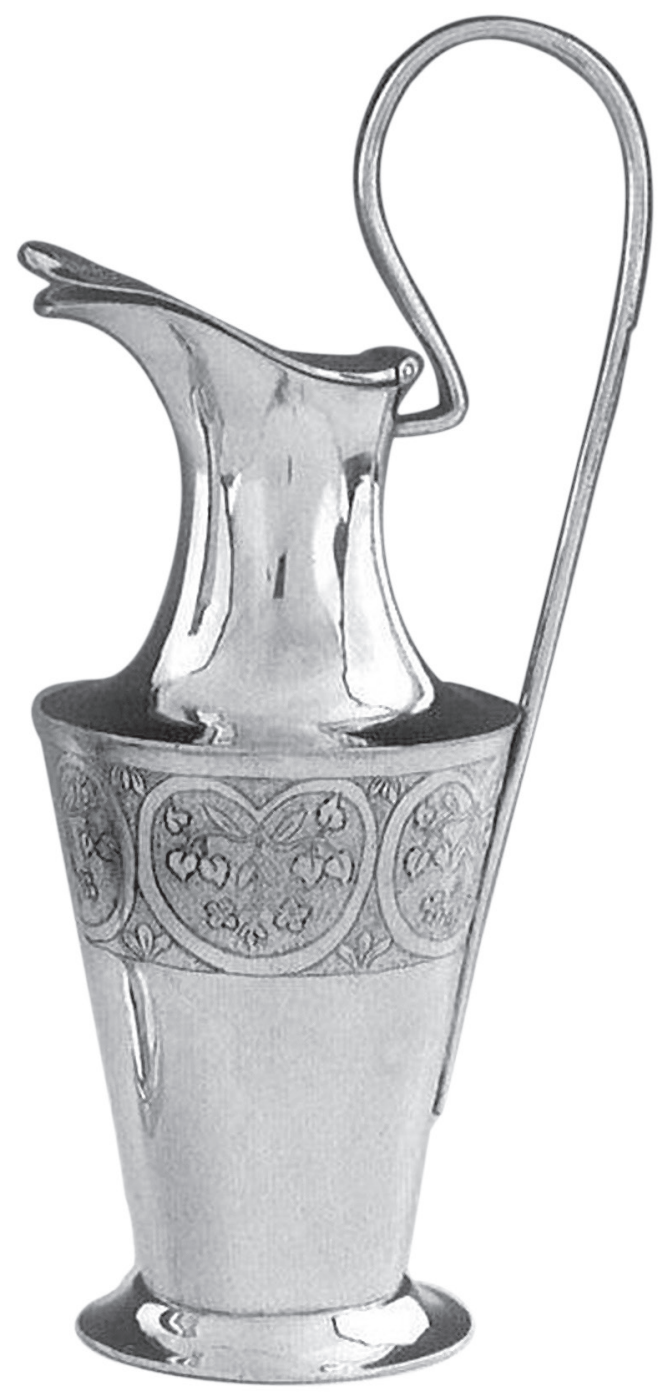

19. Fridericus Becker sen.: Boroskanna. Pozsony-Vártelek, 1813. Magántulajdon egy lekerekített végü nyéllel készült kávéskanalat, de árverésen is volt hat evőkanala. ${ }^{123}$ Újabban került elő a mesterjegy szögletes keretezésű változata egy kávéskanálról 1838-as évszámú új próbajeggyel.

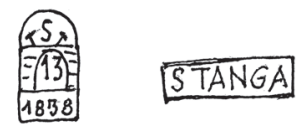

Stangának van egy másik mesterjegye is, a K:1973. Ezzel Kőszeghy próbajegy nélküli filigránmívü gombokat ismert a selmecbányai múzeum gyüjteményébőll, ${ }^{124}$ míg ugyanebben a múzeumban Toranová K:1943 próbajeggyel szintén filigránmívü csatot, a Szlovák Nemzeti Múzeumban hasonló gombot, ${ }^{125}$ ugyancsak a Szlovák Nemzeti Múzeumban pedig új 10-es próbajeggyel két filigránmívű gombot talált. ${ }^{126}$

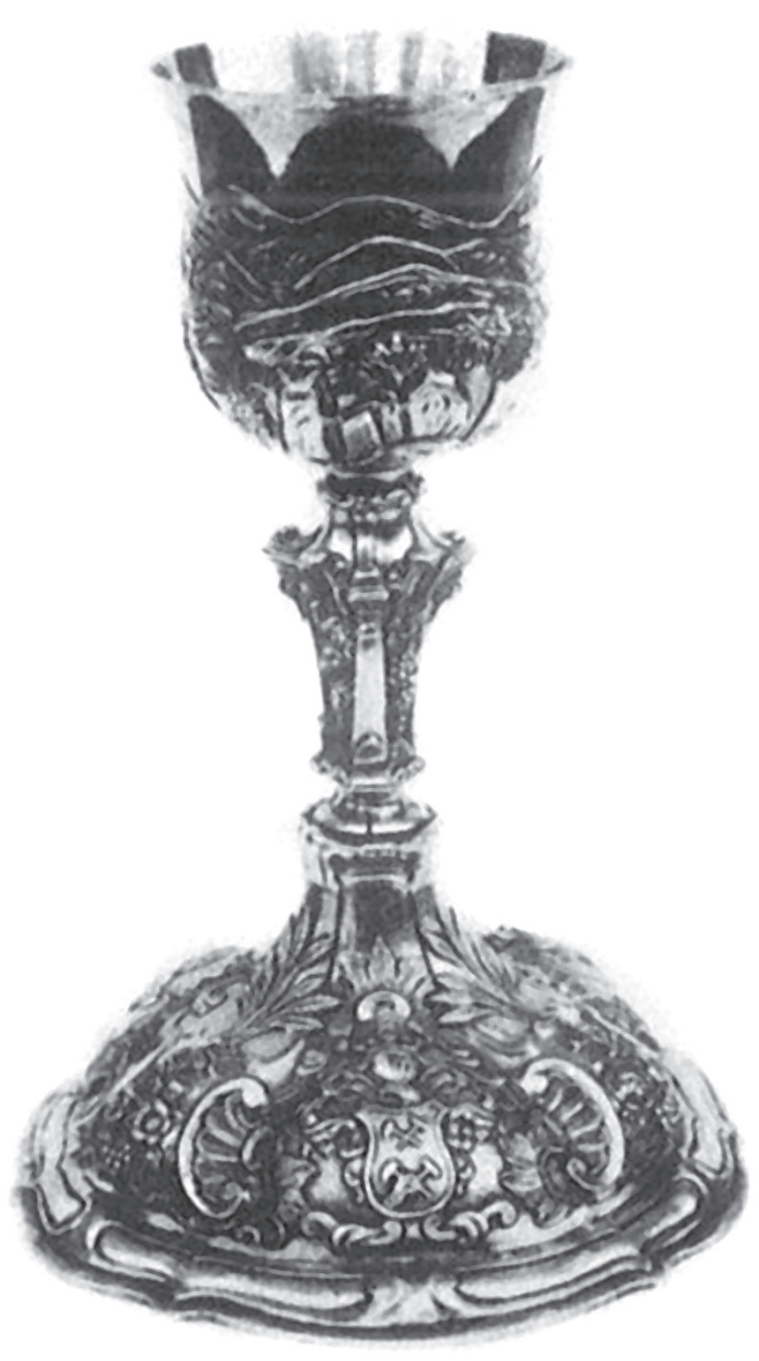

20. Johannes Stanga: Kehely.

Selmecbánya, 19. század első fele. Bélabánya, r. k. templom 


\section{(10)}

Az 1850-es évektől dolgozott Selmecbányán egy „SZLADEK" mesterjegyü (K:1976) ötvös, akinek filigrángombjai 13-as próbajeggyel (K:1950) budapesti magángyüjteményben voltak. ${ }^{127}$ Egy új 13-as próbajegy van a Szlovák Nemzeti Múzeum filigrángombján. ${ }^{128}$ Öt mentegombja 1994-ben volt árverésen, ${ }^{129}$ egy középrészén filigrángombból alakított karkötője pedig 1997-ben. ${ }^{130}$ 2003-ban egy 1860 körülre keltezett ezüst filigrángombja került árverésre, melyen a szokásos K:1976 mesterjegy mellett egy új jegy is feltünt. ${ }^{131}$

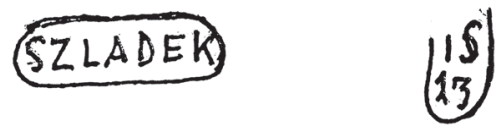

Ez a 13-as finomsági jegy mellett az IS monogramot is tartalmazza. Ez is Szladek jegye lehet. Ugyanennek egy változata, de a magyarázó „Szladek” nélkül a Szlovák Nemzeti Múzeum egy gombján is megtalálható. ${ }^{132}$

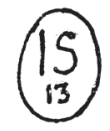

A jegyet a magyarázó jegy hiányában ott nem sikerült feloldani.

\section{Selmecbánya-Besztercebánya}

Jacobus Trauer későbbi selmecbányai ötvös inasnak szegődött 1826-ban Selmecbányán Nicolaus

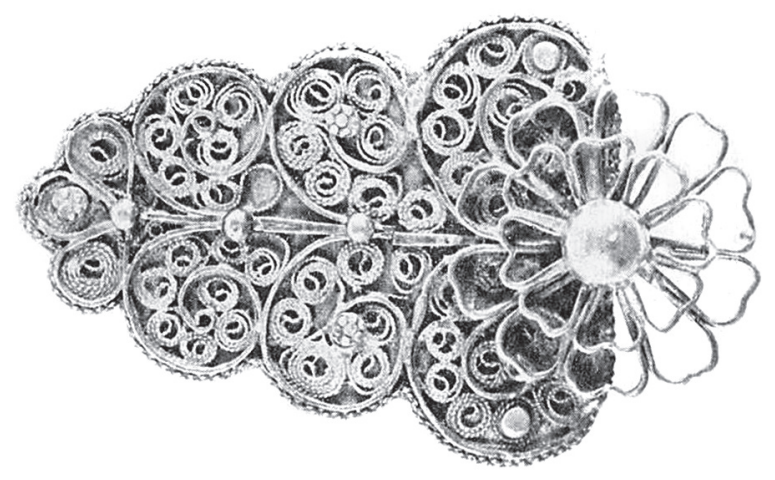

21. Johannes Stanga: Csat. Selmecbánya, 19. század. Selmecbánya, Slovenské banské múzeum
Wienerhez, de kétévi tanulás után, valószínűleg mestere halála miatt kénytelen Besztercebányára szegődni. Az addig eltöltött időről egy selmecbányai városi tanácsnok állított ki bizonyítványt. Besztercebányán Libay Sámuel szegődtette 1828. augusztus 20-án, és három év múlva, 1831. július 17-én szabadította fel. ${ }^{133}$ Köszeghy szerint 1840 körül lett mester Selmecbányán. Mesterjegyét nem ismerte. Azt, hogy a jegy kiírt „TRAUER” alakú lehet, Mihalik cikke alapján írta le egy magántulajdonú evőkanálról. ${ }^{134}$ Trauer mesterjegyét először Toranová közölte 1968ban. A téglalapba foglalt kiírt jegyet a selmecbányai Szlovákiai Bányászati Múzeum gombolyagtartóján, a besztercebányai Közép-Szlovákiai Múzeum filigráncsatján és a pozsonyi Szlovák Nemzeti Múzeum filigrángombján találta meg. ${ }^{135}$

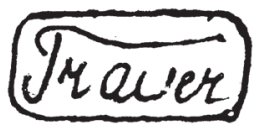

A gombolyagtartón új próbajegy is volt.

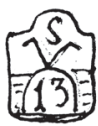

A csatot és a gombot a K:1946 próbajegy jelezte. Egy németországi magángyüjteményben bukkant fel először Trauer nyújtott ovális keretezésű mesterjegye egy kávéskanálon K:1946 próbajegy mellett. ${ }^{136}$
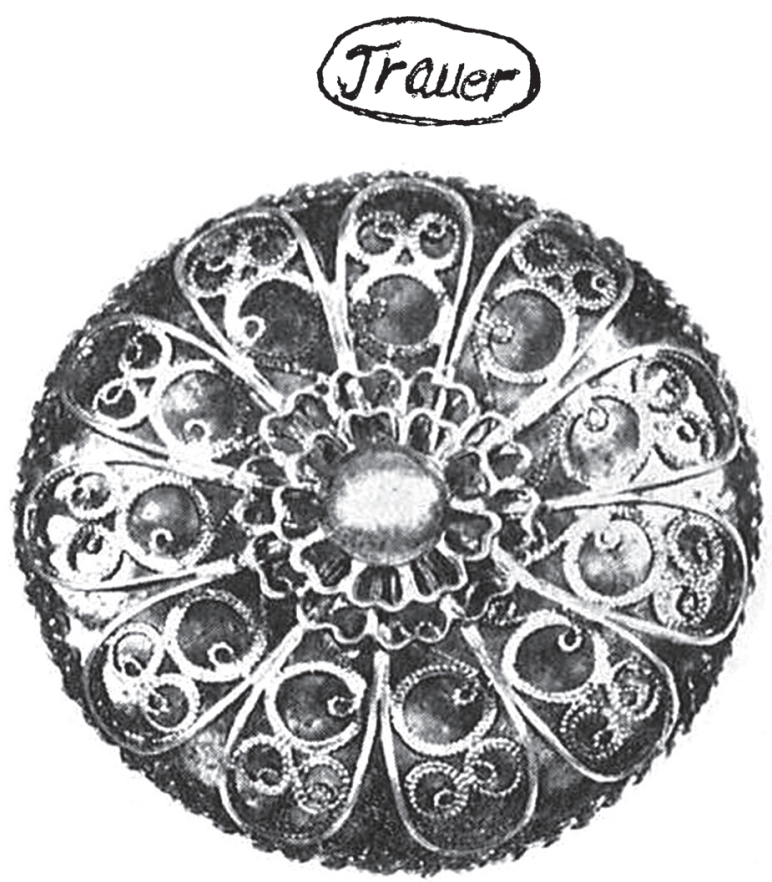

22. Johannes Szladek: Gomb. Selmecbánya, 19. század. Pozsony, Slovenské národné múzeum 
Ezzel a mesterjeggyel azóta több magángyüjteményben is találkoztam, mindig a K:1946 próbajeggyel együtt, különböző kanalakon. Egy budapesti árverésen 2008-ban hatszemélyes teáskanálkészletét árverezték az ovális mezőbe írt „Trauer" jeggyel és K:1946 próbajeggyel. ${ }^{137}$ Egy budapesti magángyűjteményben Trauer ovális keretű mesterjegyével egy füszerkanál bukkant fel, amelyet V. Ferdinánd 1848-as körmöcbányai veretü 20 krajcárosából készített. Ezen új, 13-as finomsági jelzés volt, mely így 1850 körülre keltezhető.

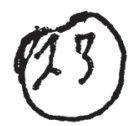

Trauer selmecbányai működésének utolsó biztos adata, hogy 1857. április 15-én elbocsátó levelet adott inasának, Emler Vilmosnak, aki négy év tanulás után átszegődött Besztercebányára Rosenberger Ferenchez. ${ }^{138}$ Valószínűleg Trauer is átköltözött Besztercebányára, mert több magángyüjteményben láttam ovális keretű mesterjegyével, de 1858-as besztercebányai próbajeggyel kávéskanalakat. ${ }^{139}$

\section{Újvidék}

Budapesti magángyüjteményben találtam egy késbakot Újvidék K:2133 próbajegyével, „A" évbetűvel (K:2136) és pajzsba írt, egymásba kapcsolt AT betűkből álló mesterjeggyel.

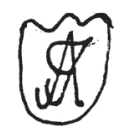

A mester Atanáz Theofánovits lehet, aki 1828 körül működött Újvidéken. ${ }^{140}$ Michael Kaupa mesterjegyével ${ }^{141}$ jelzett kávéskanalakon Újvidék új próbajegye is előkerült.

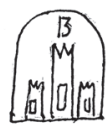

Érdekesebb ennél egy ezüstszerelékekkel készült pipa. A szár csatlakozásánál levő foglalaton Újvidék K:2133 próbajegye és „LD” mesterjegy van.

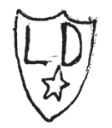

Ez a jegy Denizard (Demizard) Lajos jegye lehet, aki 1815. május 29-én kapott polgárjogot Újvidéken, és 1828-ban is ott működött. ${ }^{142}$ A pipa kupakja jelzetlen, de alatta a tüztér foglalatán PF mesterjegy és kétfejű sasos próbajegy látható.
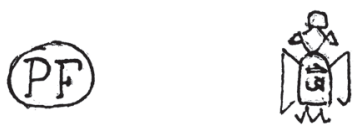

A pipa próbajegyével teljesen azonos próbajegygyel találtam budapesti magángyưjteményben egy lekerekített végü nyéllel készült kávéskanalat negatív beütésű P.FRIDL mesterjeggyel.

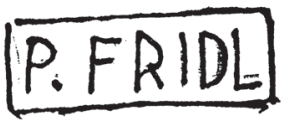

Ezekkel a jegyekkel később láttam egy evőkanalat is a budapesti múkereskedelemben. Sajnos Fridl mestert, akinek talán rokona a Pancsován 1851-ben említett Eduardus Fridl, ${ }^{143}$ nem tudom kapcsolatba hozni Újvidékkel. Így a mester, akárcsak a foglalat készítési helye egyelőre kérdéses marad. Mindenesetre utalnék azonban arra, hogy ez a sasos jegy próbajegy, és nem tévesztendő össze az osztrák császári és királyi udvari szállítók jegyével, ahol a birodalmi sas mellére illesztik a mester monogramját. Az mesterjegy, amely mellett mindig szerepel a szabályos próbajegy is. Ez a jegy pedig próbajegy, amelyben a sasra a finomságot jelző számot helyezték. Használatát valószínűleg Magyarország déli részén kell keresni, esetleg Szerbiában. Hasonló próbajegy nemrég LK mesterjegyü, bütykös végü nyéllel készült kávéskanalakról is előkerült.

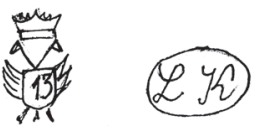

Ezek meghatározásához is további kutatásra van szükség.

A budapesti mükereskedelemben volt 1999-ben egy tejmerő K:2133 újvidéki próbajeggyel és IN/T mesterjeggyel.

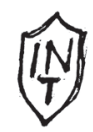

A mesterjegy, igaz csak csonkán, többször is előkerült. Egy hegyes végű nyéllel készült evőkanálon a K:2133 próbajegy és Kőszeghynél nem kö- 
zölt B évbetű mellett a jegy felső része (IN), majd egy hegyes végü nyéllel készült tejmerőn a K:2133 próbajegy mellett a jegy alsó része $(\mathrm{T})$. A jegyek a csonka körvonal és jegytöredékek segítségével jól kiegészíthetők a fenti teljes mesterjeggyé. Sajnos a mesterjegy feloldása eddig nem sikerült.

\section{FÜGGELÉK}

1.

Az óbudai izraelita hitközség anyakönyveiben ${ }^{144}$ említett azon arany- és ezüstművesek, akik feltehetően már 1867 előtt dolgoztak Óbudán, és így munkáikat Óbuda próbajegyével jelezhették. A sok hasonló vagy azonos név miatt csak azokat vettem számba, akiknek foglalkozását egyértelműen beírták az anyakönyvbe.

Abeles, Herman (26 éves leánya házassága 1859. június 19., halála 54 évesen 1862. május 9.)

Baur, Joseph (leány házassága 1851. augusztus 10. halála 83 évesen 1859. október 31.)

Beck, Emanuel (házassága 25 éves korában 1851. november 2.)

Böhm, Salamon (leánya házassága 1861. október 6, másik leány házassága 20 évesen 1874. május $31 ., 25$ éves fia házassága 1874. augusztus 9.)

Braun, Herman (24 éves fia, Moritz, házassága 1865. május 14., halála 53 évesen 1871. május 11.)

Braun, Josef (házassága 25 évesen 1860. október 28.)

Braun, Moritz (házassága 24 évesen 1865. május 14.)

Deutsch, Jacob (házassága 26 évesen 1868. június 1.)

Druker, Jacob (21 éves leánya házassága 1851. október 28.)

Druker, Jacob L. (halála 76 évesen 1863. január 19., lehet, hogy azonos az előzővel.)

Druker, L. H. (halála 69 évesen 1863. április 6.)

Druker, N. H. (fia házassága 1873. március 23.)

Fischer, Jacob (házassága 32 évesen 1866. október 14.)

Franke, Simon (házassága 31 évesen 1863. február 8.)

Gross, Adolf (házassága 29 évesen 1857. november

18.)

Gross, Moritz (házassága 30 évesen 1859. december 4.)

Grünwald, Moritz (házassága 59 évesen 1890. december 29.)

Hauser, Samson (24 éves fia házassága 1852. október 24.)

Hautrucz, Ignacz (házassága 60 évesen 1894. június 20.)

Kohn, Wilhelm (házassága 50 évesen 1851. augusztus 10.)
Lemberger, Salomon (30 éves fia házassága 1857. december 1.)

Löwinger, Josef (fia házassága 1868. november 8. halála 69 évesen 1869. július 20.)

Rubin, Adolf (házassága 31 évesen 1871. június 11.) Schön, Simon (házassága 29 évesen 1855. december 16.)

Schulhof, David (32 éves leánya házassága 1852. október 10.)

Zilzer, Samuel (házassága 26 évesen 1872. szeptember 22.)

2.

Az óbudai izraelita hitközség 1850. januári öszszeírásában (MOL Filmtár A3584 sz. doboz) szereplő aranyművesek, ezüstművesek (Goldarbeiter, Silberarbeiter) és ékszerészek (az összeírásban: Jovlier, Jouvlier, Juvlir, itt egységesen Juwelier) életkorukkal együtt:

Abeles, Herman (46) Silberarbeiter

Adler, Jonas (37) Silberarbeiter

Bek, Emanuel (23) Goldarbeiter-gesell

Böhm, Salomon (34) Silberarbeiter

Braun, Herman (42) Silberarbeiter

Drucker, J. L. (54) Goldarbeiter

Drucker, L. H. (55) Silberarbeiter

Frankl, Israel (18) Silberarbeiter

Löwy, Joachim (37) Goldarbeiter

Marvay, Simon (33) Juwelier

Schosberger, Moritz (28) Goldarbeiter

Schulhof, J. L. (32) Silberarbeiter

Schulhof, Salomon (41) Silberarbeiter

Schulhof, Wolf (42) Silberarbeiter

Schwarz, Emanuel (29) Silberarbeiter

Schwarz, Josef (40) Silberarbeiter

Silberstein, Anton (kora nincs beírva) Juwelier

Weiss, Jacob (26) Juwelier

Weiss, Joachim (20) Juwelier

Wizinger, Herz (kora nincs beírva) Juwelier 


\section{JEGYZETEK}

1 Köszeghy Elemér: Magyarországi ötvösjegyek a középkortól 1867-ig. Budapest 1936.

2 P. Brestyánszky Ilona: A pest-budai ötvösség története. Budapest 1977.

3 BÁV 55. Müvészeti aukció (2009. november 12.) 615. sz.: Pesti empire boroskancsó. Ezüst, 329 gr. Kerek talpon amfora formájú edény, vállán karéjos frízben virág- és növénydíszek, enyhén boltozatos billenő fedél és ívelt fogó. Talpperemén jelzett: Pest, 1817-18, „q" évbetü. Starzer Antal. (Újonnan felbukkant, eddig még nem publikált AS mesterjegy ovális mezőben.) Kőszeghy 395, 462. M: $23,6 \mathrm{~cm}$.

4 P. Brestyánszky i. m. 352.

5 Földes Emilia: Ötvöskatalógus. Budapest 1978, 451. sz.: Filigránkosárka, filigránmívű. Hatszögletű, hosszúkás formájú, hat egyforma méretü és díszítésü oldallappal. Mustrájuk ágas-bogas, bogyós, csipkeszerü filigránmunka. Felső és alsó részén körbefutó pánt. Alja sima, hatszögletü ezüstlemez. Két nagy füle ívesen hajló indás mustrájú filigránnal díszített. Hat csavart filigránmívű lába van. Mesterjegy belül az alján: téglányban VM monogram, Köszeghy 804. Próbabélyeg uo.: 1800 K. Köszeghy 393, Brestyánszky 119. M: 75 mm, fenéklap: 143×61 mm. Ltsz.: IP.68.84.

6 Pest-Belváros születési anyakönyve: Magyar Nemzeti Levéltár Országos Levéltár (továbbiakban: MOL) Filmtár A74 sz., halotti anyakönyvei: MOL Filmtár A89,90 sz. dobozok.

7 P. Brestyánszky i. m. 290.

8 Földes i. m. 450. sz.: Mentekötő, aranyozott ezüst, sodronydíszes. Levágott sarkú, négyzet alakú lemezek, filigrános sodronydísszel, középen és a sarkokban sötétvörös almandin kövekkel. A lemezeket láncok kötik össze egymással. A legnagyobb lemezt 6 kő díszíti. A lemezek sodronyhálója szélén hullámos, a kövek körül indamotívum van. Mesterjegy a lemezek hátoldalán: VM monogram. Próbabélyeg uo.: 1824, Kőszeghy 400, Brestyánszky 130. H: 800 mm. Ltsz.: 55.130.1.1-2.

9 Nagyházi Galéria és Aukciósház 117. Aukció (2005. május 28.) 695. sz.: Női gyürü. Pest. 19. sz. közepe, antik arany, „Pesth” jelzéssel, Stenger Vilmos, öntött, almandinfoglalással, szélein vonalas dísszel. 4,7 gr.

10 Földes i. m. 462. sz.: Pecsétgyürü, arany, öntött. A széles, domború abroncs a pecsétfej foglalatává szélesedik. Az ellipszis alakú rubinkoronája laposra csiszolt, DR Rot bevéséssel. Mesterjegy az abroncs belső oldalán: LS monogram. Helybélyegző uo.: Kőszeghy 471, Brestyánszky 233. Aranypróba 3. Kőszeghy 445, Brestyánszky 185. Á: 19 mm. Ltsz.: 15275.

11 Pest-Belváros születési anyakönyvei, MOL Filmtár A75. sz., halotti anyakönyvei, MOL Filmtár A92 sz. dobozok, Pest-Terézváros születési anyakönyvei, MOL Filmtár A96 sz., házassági anyakönyvei, MOL Filmtár A116 sz. dobozok.

12 Pest-Belváros házassági anyakönyvei, MOL Filmtár A84 sz. doboz.

13 MOL Z195. A Budapesti Kereskedelmi és Iparkamara, illetve jogelődei iratai. 42. sz. doboz. 995/16134. sz. Schickinger Adolfot Brestyánszky és Horváth Henrik (A pesti arany- és ezüstmüvesek névsora. Budapest Régiségei XII. 1937, 251-257) sem ismerte.
14 Waltraud Neuwirth: Wiener Silber 1781-1866. Wien 2002, 215.

15 Uo.: 234-235.

16 P. Brestyánszky i. m. 227.

17 P. Brestyánszky i. m. 224.

$18 \mathrm{Az}$ Ernst-Múzeum Aukciói. XII. Különböző magánbirtokból származó mütárgyak. Budapest 1920, 1203. sz.: Gombolyagtartó, ezüstfiligrán, félgömbös testtel. SE mesterjegy, Óbuda 1810.

19 Polgár Galéria és Aukciósház 55. Tavaszi Művészeti Aukció. 2005. május 18., 266.sz.: Óbudai filigrános teaszürő. 13 latos antik ezüst, 18,5 cm, bruttó 21 gr. Jelzett: Engel Sámuel, 1820 körül (B:85,100, vagy K:362,371). Kerek, virágrozettákkal tagolt fenekén 12 sziromból álló pártázatú szegély. Sötétbarnára pácolt, esztergált, baluszteres fanyél.

20 P. Brestyánszky i. m. 228. Mindhárman szerepelnek Óbuda 1828-as összeírásában (MOL Filmtár B128 sz. doboz), de sem az anyakönyvben, sem Schoen Arnold munkájában (Óbuda múltjából. Budapest 1935.) nem találhatók.

21 P. Brestyánszky i. m. 228. Földes i. m. 79. sz.

22 Dorotheum 2095. Kunstauktion. Wien, 2005. június 2., 184.: Paar Budapester Biedermeier Kerzenleuchter mit 4-flammiger Girandoleneinsätzen. Silber, rund, hochgewölbter Fuß mit Ornamentband mit drei Volutenarmen, Rosenblütenwülste, vasenförmiges Zentrum, Tropfränder mit Blattband, Höhe 46,5 cm, Gewicht 1723 g, Girandoleneinsätze ungemarkt, Kerzenleuchter mit Meisterzeichen JS=Isaac Seitz bzw. Ignaz Stigler (Köszeghy 377), Beschauzeichen Altofen 1833.

23 Pless és Fox Ékszerüzlete 76. Árverés. 1996. május 28., 71. sz.: Antik kanál. Beszterce 1826. Johannes Deutschmann. 6,66 gr. (Mind a város, mind a mester megnevezése téves.)

24 BÁV 43. Művészeti Aukció, 2003. október 30. 898., sz.: Kosárka. Filigránezüst, 16 gr, ezüstsodrony füllel. Jelzett: Óbuda, 1820, JD mesterjegy. H:8,5 cm.

25 Függelék 2. A gyüjtött adatok egymással ellentmondóak. Az 1850-es összeírás alapján feltételezhetően 1796ban született. A Függelék 1 szerint az anyakönyvben az szerepel, hogy 1863-ban 76 évesen halt meg, vagyis 1787 körül születhetett. Általában a halálozáskori életkor szokott téves lenni, mivel a hátramaradtak, ha egyáltalán volt közeli rokon, nem tudták a pontos életkort. Mindenesetre 1820 körül Jacob Drucker már dolgozhatott Óbudán.

26 Schoen Arnold: Óbuda múltjából. Budapest 1935, 52.

27 A M. Kir. Postatakarékpénztár Árverési Csarnokának 1938. évi külön Aukciója (1938. január 22.), 288. sz.: Ékszerládika. Ezüstfiligrán, színes ékkövekkel díszítve. Óbuda 1820. Az Előszóban (9.): Ismeretlen óbudai JD jegyü ezüstmúvest örökít meg egy filigrános ládika álékszerekkel díszítve, hitelesító jegyén az 1820-as évszám jelzi a készítés idejét.

BÁV 110. Festményaukció, mütárgy és szőnyegárverés, 2002. december 11-13., 449. Vizitkártyatálka. Ezüst, 80 gr. Ovális forma, öblében trébelt, stilizált leveles díszítéssel, peremén ráforrasztott tulipán motívumsor. Több helyen javított, kissé deformált. Jelzett: Óbuda, 1820, JD feloldatlan mesterjegy.

28 A régi Buda és Pest iparmúvészetének kiállítása. Iparmúvészeti Múzeum. Budapest 1935, 36. sz. 
29 MOL Filmtár B128 sz, doboz.

30 Keresztelőérem. Óbuda 1833 (B:91), B évbetű (B:95). Polák József B:102var. Hátul vésett: Gewidmet den/ Joseph Kunig/ von seiner Firmpather/ Joseph Müller.

31 Földes i. m. 70, 71, 72 sz. A 71. számú két füszerkanál az 1942-es Almásy-aukcióról került a múzeumba: Gróf Almásy-Teleki Éva Müvészeti Intézete (volt ErnstMúzeum) VIII. Aukció, 1942. március 9., 869. Teaszűrő és két sókanál. Filigránezüst. Óbuda, 1840 körül. (Az évszám pontatlan, a teaszürő ma nincs a múzeumban.)

32 P. Brestyánszky i. m. 226.

33 István Heller: Ungarische und siebenbürgische Goldschmiedearbeiten. München 2000, 43.: Taufmedaille in Silberrahmen. Josef Polak, datiert 1833. Silber, graviert, Medaille geprägt, Rahmen in Filigranarbeit gefertigt. D: Medaille 6,0 cm, mit Rand 10,0 cm. „Joseph Kubinszky gebr: D: 2. August 1834, Taufpathe war Joseph Thoma."

34 Pless és Fox Ékszerüzlete. Árverés 1990. december 17-én, 10. sz.: Keresztelőérem, ezüstfiligrán keretben keresztelési jelenetet ábrázoló érem. Hátán 1834-ből származó, Ottilia Dirner születésére készült vésett emlékszöveg. Polák József (B:102), Óbuda 1833 és B évbetü. A filigrán hibás, kissé hiányos.

35 Polgár Galéria és Aukciósház 57. Ôszi Művészeti Aukció (2005. október 13.), 330.: Óbudai keresztelőérem. 13 latos antik ezüst, $24 \mathrm{gr}, 10 \mathrm{~cm}$. Jelzett: Polak József, B évbetü, 1833 (B:91, 95, 102). Hét karéjos, filigránkeretben, gyürübe foglalt medál a keresztet tartó kis Jézus figurájával és körirattal: ERLÖSER DER WELT. Alul az éremművész jelzése: L. Heuberger F(ecit). Fölül díszes akasztó.

36 Pless és Fox Ékszerüzlete 146. Árverés 2002. március 25., 146.: Keresztelőérme, filigrántechnikával készült, kissé sérült, horpadt, a belső érmerészen „Heuberger” felirat, átmérő $11,5 \mathrm{~cm}$. Óbuda 1835, Polák József. Súly 10,0 g

37 BÁV 52. Ékszeraukció, 2000. május 30., 232.: Keresztelőérem. Ezüst, filigrándíszítésű keretben Jézus keresztelése ábrázolás Heuberger jelzéssel, hátoldalon vésett felirattal, függesztőkarikával. Óbuda, 1838, B évbetü, Polák József. Súly 54,4 g.

38 BÁV 49. Müvészeti Aukció (2006. november 9.) 761.: Óbudai keresztelőérem. Ezüst, filigránmívü keretben. Érmén a gyermek Jézus kereszttel, körben német nyelvü felirat: ERLÖSER DER WELT. L. HEUBERGER F. Hátulján ajándékozási véset: Anna Carl/ geboren den 31, Mai 1841/ Taufpathe War F. Weisz. Jelzett: Óbuda 1838 (B évbetű) Polák József (B:93, 95, 102). Átm.: 7,5 cm.

39 M. Kir. Postatakarékpénztár Árverési Csarnoka 103. Aukció. 1942. március 27. 1431.: Keresztelőérem. Ezüst. Óbuda 1845. (2. oldal: Az aukcióra kerülő tárgyak általános leírása; 1431.: Polák József)

40 Heller: i. m. 44.: Gewürzbehälter auf einem Dreifuß. Meister mit dem Familienname STERN, datiert 184(?) Als Gewürzbehälter dient eine halbrunde getriebene Silberschale mit profiliertem Rand, die auf drei schlanken, leicht gebogenen Stützen mit rollenförmigen Füßen steht. (Markentafel 43).

41 Földes i. m. 73.: Füszertartópár, kalapált, filigránmívü. A tartócsésze kör alakú, öblös, sima, díszítetlen felületü, kívülről kettős vonalperemmel. Három filigránmívü, stilizált levélformájú, kis hengeralakban végződő lába kifelé hajlik. M: 55 mm, Á: 96 mm (Ltsz.:
23664.1-2.) Mesterjegye: kívül a csésze alján téglányban STERN. Próbajegye 1845.

42 P. Brestyánszky i. m. 354.

43 MOL Filmtár B128. sz. doboz.

44 P. Brestyánszky i. m. 223.

45 BÁV 56. Művészeti Aukció (2010. május 20.) 625.: Óbudai biedermeier pipa. Faragott tajték antik ezüstkupakkal, pipakosarán ezüstmontírozással. Patentzáródású csigavonalas, áttört és bordázott díszítésű zsanéros kupak. Szára hiányzik. Ezüstfoglalatán jelzett: Óbuda 1835. B évbetü., Josephus Adler. Kőszeghy 365, 369, 378. H: 17 $\mathrm{cm}$.

46 https://familysearch.org

47 Kalocsa halotti anyakönyvei, MOL Filmtár A3145 sz. doboz.

48 A Nemzeti Múzeum Régiségtárának gyarapodása 1914-ben. In: Közlemények a Nemzeti Múzeum Érem- és Régiségtárából. I. 1916, 1.sz., 65.

49 Grotte András: Kísérlet néhány magyarországi ötvösjegy feloldására II. Müvészettörténeti Értesítő XL. 1991, 69.

50 Ridovics Anna szíves közlése.

51 A magyar pipaművesség története. Történelem a magyar pipákon. Kiállítási katalógus. Szerk.: Haider Edit, Ridovics Anna. Budapest 2000, Kat.: 20/30. sz. Ltsz.: MNM D.1914.16.13

52 Neuwirth i. m. (14. j.) 197.

53 Köszeghy i. m. 158, Eva Toranová: Kežmarsky zlatnícky cech. Zbornik SNM LXIII. Historia 9. 1969 (továbbiakban: Toranová 1969), 284, Uö: Goldschmiedekunst in der Slowakei. Hanau 1982 (továbbiakban: Toranová 1982), 237.

54 Ez később németországi magángyưjteménybe került, és Londonban árverezték el. (Dr. Heller's Lexicon. Sotheby's London, 4, December 2012, No. 145.)

55 Köszeghy i. m. 159, Toranová 1982, 237.

56 Köszeghy i. m. 159.

57 Eva Toranová: Vyrobky domácich zlatníkov a pamiatky zlatníckych cechov v zbierkach slovenskych múzeí. Bratislava 1968 (továbbiakban: Toranová 1968), 51. sz, Inv.č. UH 3999.

58 Toranová 1969, Katalog 8. sz.

59 Az Országos Magyar Iparmúvészeti Múzeum Régi ezüstkiállításának leíró lajstroma (szerk.: Csányi Károly). Budapest 1927, 596. sz.: Talpas cukortartó fedővel, urna alakú, tojásdad testen empire palmettás fríz, boltozatos tagozott födelén gyümölcsök. M: $21,5 \mathrm{~cm}$. JO mesterjegy. Magyar, empire. (Wertheimer Adolf)

60 BÁV 43. Müvészeti aukció (2003. október 30.), 923. sz. Empire gyertyatartópár. Ezüst, 529 g. Talpán igényesen trébelt lándzsaleveles növényi díszítmény. Egyenes vonalú, tizenkét lapra osztott szár recézett tagoló gyürükkel. Öntött, empire gyertyacsésze vésett és poncolt motívumokkal. Jelzett: Késmárk, 1810 körül. Jacobus Olmützer junior. Köszeghy 933, 949. M: 25,5 cm. Ugyanez: BÁV 46. Művészeti aukció (2005. május 5.), 837.sz.

61 Állami Zálogház és Árverési Csarnok N. V. 136. számú aukciója (1949. március 30.), 1204. sz.: Talpas cukortartó fedővel. Ezüst, trébelt díszítéssel. 355 gr. Késmárk. Jacobus Olmützer junior. XIX. század eleje. (Ugyanez: Állami Zálogház és Árverési Csarnok N. V. 137. számú aukciója (1949. június 1.) 1065. sz.) 
62 Nagyházi Galéria és Aukciósház. Mütárgyárverés (1999. április 29.), 341. sz.: Fedeles cukortartó. Ezüst, kalapált, ovális, csavart dróttal szerelt peremmel, két leveles tapadású füllel, tagolt fedelén leveles körte. M: $12 \mathrm{~cm}$, 427,7 g. (Kőszeghy 933, 949.)

63 BÁV 61. Müvészeti aukció (2012. november 15.), 624. sz.: Késmárki empire boroskanna. Ezüst, 409 g. Trébelt, gyöngysorral díszített, ívelt talpon körte formájú edény. Oldalán maszkaronés, stílizált fafül, zsanéros fedelén gyümölcsdísz. Füle restaurált. Talpperemén és fedelén jelzett: Késmárk, 1810 körül, Jacobus Olmützer junior (Köszeghy 923, 949). M: 23,2 cm.

64 Sotheby's London. Fine English and Foreign Silver and Plate (20thn October 1977.), No. 109. An early 19th century Czechoslovakian coffee jug and hot milk jug, the vase-shaped bodies embossed with bearded busts within matted and leaf chased ovals, similar ornament at the necks, covers and pidestal bases, 11,5 in. $(29,5 \mathrm{~cm})$ and 10,5 in. $(27 \mathrm{~cm})$ high, by Jacobus Olmützer Jr. Kesmark, circa 1810, 23 oz, 12 dwt (all in). (Sajnos, a katalógusban nincs fényképük.)

65 Dorotheum 2290. Kunstauktion. Silber. (16. Mai 2011.) 572.: Kesmarker Zuckerdose. Silber, oval, Scharnierdeckel mit plastischen Blumenknauf, vier Füße. Wappengravur. $135 \times 10 \times 11,5 \mathrm{~cm}$. Gewicht $387 \mathrm{~g}$. Meisterzeichen $\mathrm{AH}=$ Andreas Hanzely, Beschauzeichen: Kesmark um 1780.

66 BÁV 59. Müvészeti aukció (2011. november 10.), 680.: Felvidéki barokk gyertyatartó. Ezüst 222 g. Trébelt, nyolcszögletü talpon gyürükkel tagolt szár, kehely formájú gyertyacsészével. Talpán felül jelzett: 13 latos fémfinomsági jellel, valamint feloldatlan, AH mesterjeggyel, ill. beütött „IHLS” tulajdonosi monogram. Magyar 1760 körül. M: 16,6 cm.

67 Köszeghy i. m. 158-159, Toranová 1969, 284-285. Toranová 1982, 237. említi, hogy az idősebb Andreas Hanzely Besztercebányán volt inas, míg az ifjabb az apjánál Késmárkon. Besztercebányán működött Samuel Hanzely (1696-1712) és Johann Hanzely (1730-1745), de Hanzely András inast Besztercebányán korábban nem említettek. (H. Mihalik Sándor: Besztercebányai ötvösök a XV.-XIX. században. Múzeumi és Könyvtári Értesítő XII. 1918, 36-53, 127-142.), de Kapossy szerint is Hanzely András Hanzely János fia volt, és Besztercebányán volt inas: Kapossy János: Magyarországi ötvösök a XVIII.-XIX. században. Budapest 1934, 18.

68 Köszeghy i. m. 158-159.

69 Toranová 1969, 289. Katalog 9, 276, 7. kép.

70 Galerie Jürg Stuker, Bern. Auktionen 96-101 (13. November 1970.), 1272.: Zuckerdose, Kesmark um 1750. Meistermarke Andreas Hanzely sen. Bauchige Ovalform mit gewölbtem Klappdeckel. Wandung und Deckel mit vier geschweiften Rippenfeldern, als Knauf eine Frucht an belaubtem Zweig. Innen Spuren alter Vergoldung. $13 \times 10 \times 10 \mathrm{~cm}$. Gewicht 250 g. Taf. 13. („,Szappantartó típus")

71 Sotheby's Geneva (12th May 1987). European Silver, Nr. 100.: An Hungarian Standing Cup and Cover, Andreas Hanzely jnr., Kesmark circa 1800, the body and cover embossed with pineapple lobes, sheet scroll-work finial, on a stem in form of the young Bacchus below a leafy canopy, on a matching circular foot, marked on body and cover, $474 \mathrm{gr}, 30 \mathrm{~cm}$ high. Ugyanez: Judit H. Kolba:
Hungarian Silver. The Nicolas M. Salgo Colllection. London 1996, Nr. 102.

72 A historizálás nem csak Hanzely serlegének jellemzője. Nagyjából vele egy időben, 1810 körül készítette Pozsony-Vártelken Adam Renner szintén 17. századi minta alapján azt a fedeles serleget, amely most a budapesti Iparmúvészeti Múzeum tulajdona. (Az európai iparmüvészet stíluskorszakai. Historizmus és eklektika. Kiállítás az Iparmüvészeti Múzeum gyüjteményéből. Budapest 1992, 363. sz. Ltsz. 50.4.)

73 BÁV 55. Müvészeti aukció (2009. november 12.), 616. sz.: Késmárki empire tejszínkiöntő. Ezüst, 113 g. Trébelt, öblös edény, ívelt füllel. Billenő fedelén plasztikus gyümölcsdísz. Talpán jelzett: Andreas Hanzely Senior, valamint 1966 utáni pesti hitelesítő jegy. Kőszeghy 934, 947. Ugyanez: BÁV 56. Múvészeti aukció (2011. május 20.), 661. sz.

74 Heller i. m. (33. j.) No. 85.: Teller mit gravierten Wappen der Familie Bezerédy. Ugyanez: Istoán Heller: Europäische Goldschmiedearbeiten 1560-1860. München 2003, No. 187.

75 Grotte András: Kísérlet néhány magyarországi ötvösjegy feloldására XIII. Művészettörténeti Értesítő 60. 2011 (továbbiakban: Kísérlet XIII.), 111.

76 Toranová 1969, 290, Katalog 12 (8c kép) és 13.

77 Grotte András: Kísérlet néhány magyarországi ötvösjegy feloldására II. Müvészettörténeti Értesítő XL. 1991, 74, és Uő: Kísérlet néhány magyarországi ötvösjegy feloldására VIII. Müvészettörténeti Értesítő LI. 2002 (továbbiakban: Kísérlet VIII.), 331.

78 Polgár Galéria és Aukciósház 88. Tavaszi Múvészeti Aukció (2011. május 17.), 368.: Antik csengő. 12 latos antik ezüst, 156 g, 10x7 cm. Jelzett: Löcse 1830 körül, JG (Johannes Gemza) mesterjegy. (A város helyesen: Késmárk.)

\section{Kísérlet XIII., 113-114}

80 BÁV 51. Müvészeti Aukció (2007. november 8.), 784. sz.: Nagybányai rokokó misekehely. Tüzaranyozott ezüst, 400 gr. Trébelt, hat részre tagolt, lépcsőzetes talp, fazettált, körte alakú nódusszal és kihajló peremü kupával. Talpperemén beütött latin nyelvű ajándékozási felirat (kiegészítésekkel): SACEL(LO). S(ANCTAE). ROSAL(IAE). VIRG(INIS). EX MUNIFIC(ENTIA). P(ERILLUSTRISSIMI). D(OMINI). JOSEPH(I). PAULKOVICS SENATOR NAGYBANIEN(SIS). ET ELISABETH(AE). KOFFLER CONSORT(AE). EJ(US). CUR(A). ET OBL(ATIONE). ANNO 1780.

Talpperem alján jelzett: benyomott JoGy mesterjegy, 12 latos finomsági jelzés, nagybányai városjegy. Köszeghy 1263. M. $21 \mathrm{~cm}$.

81 Balogh Béla, Oszóczki Kálmán: A nagybányai ötvöscéh a XV-XVII. században. In: Müvelődéstörténeti tanulmányok. Bukarest 1979, 121-137.

82 Sándor Mihalik: Versuch einer Zentralisierung des ungarisches Punzierungswesen im 18. Jahrhundert. Acta Historiae Artium VII. 1961, 266.

83 Köszeghy i. m. 228.

84 Sotheby's Genf. European Silver. 12th November 1985, 11.: A Hungarian Sugar box, maker's mark IG over 13 (Köszeghy No. 1267), Nagybánya, c.1760, the oval body and cover fluted at intervals, stamped with the initials E.P. marked on base and lid, $211 \mathrm{gr}, 12,4 \mathrm{~cm}$ wide.

85 Köszeghy i. m. 228. 
86 Nagyházi Galéria és Aukciósház. 123. aukció. Ezüsttárgyak és ékszerek (2005. december 10.), 38.: Füszertartó. Nagybánya 1800 körül, antik ezüst, Josephus Huszár, ovális forma, négy öntött lábon álló, belül tűzaranyozott, $87,2 \mathrm{gr}, \mathrm{M} .4 \mathrm{~cm}$.

87 BÁV 50. Művészeti Aukció (2007. május 24.), 785.: Nagybányai klasszicista sótartó. Ezüst, 87 gr, belül aranyozva. Négy öntött lábon álló ovális tálka, peremén barázdált díszítéssel. Jelzett a fenekén: Nagybánya, XVIII. sz. vége, Josephus Huszár, Kőszeghy 1264 variáns, 1269. M: $4 \mathrm{~cm}, \mathrm{H}: 7,5 \mathrm{~cm}$.

88 Dorotheum 2226. Kunstauktion. Silber (11. Mai 2009.), 61.: Neustädter klassizistische Mokkakanne. Silber, rund, gebaucht, Scharnierdeckel mit Eichelbekrönung, Holzhenkel, Höhe: 20,3 cm, gewicht 403 gr. Meisterzeichen 13/IH. Stadtmarke Neustadt (Magybánya), um 1780.

89 Magyar Református Egyházak javainak tára. Kárpátaljai Református Egyház I-IV. II. Beregi Egyházmegye 1. Szerk.: Küllős Imre, P. Szalay Emóke. Budapest 2000. Bilke. Úrasztali felszerelési tárgyak, 131. 5. Kenyérosztó tányér. Ezüst, vésett felirattal. Egyenes szélü, vízszintes peremü, lapos öblü tányér. A peremén vésett felirat: NEHAI TTES ÉS NEMZETES KOMLOSI LAJOS ÚR EL MARADOT ÖZVEGYE TTE TSEPEI ZOLTÁN KLÁRA ASZONY ISTENES INDULATBOL AJÁNDÉKOZTA A KOMLOSI RFOR ECCLANAK AO 1799 I MARTI. Beütött hitelesítő és mesterjegy. Kőszeghy 1936. 1265,1269. Készült: XVIII. század vége, Nagybánya, Huszár József munkája. Átm.: $17 \mathrm{~cm}$. A jegy rajzáért és fényképéért külön köszönettel tartozom P. Szalay Emőkének.

90 Magyar Református Egyházak javainak tára. Kárpátaljai Református Egyház I-IV. I. Máramaros-Ugocsa Egyházmegye. Szerk.: Küllős Imre, P. Szalay Emóke. Budapest 1999. Forgolány, 106: Úrasztali felszerelési tárgyak. 1. Kehely. Ezüst, aranyozott, vésett felirattal. Peremes, domború talpú, széles szárú, felül levélsorral, gyưrüvel, nódusza körte alakú, kuppája alul domború, alig szélesedő magas oldallal. Felirat a talp peremén: EZEN POHARAT NAGY MIKLÓS ISTENES INDULATBÓL AJÁNLOTTA A FORGOLÁNYI REF. SZENT ECCLANAK AO 1798 DIE DEC. Jeggyel ellátva: Kőszeghy 1936, 1265. Készült: Nagybánya, XVIII. század vége. Talpátm.: $12,8 \mathrm{~cm}$, szájátm.: $9 \mathrm{~cm}, \mathrm{~m} .: 25,7 \mathrm{~cm}$.

91 P. Szalay Emóke: Feltételezett nagybányai ötvösmunkák Kárpátalján. Adatok a nagybányai ötvösséghez. Néprajzi Látóhatár X. 2001, 547-548.

92 Dorotheum 2130. Kunstauktion (1. Juni 2006.), 85.: Neustädter Kaffeekanne. Silber, rund, abgesetzter Fuß, Randzonen mit Perlband, eingezogene Halszone, Schnabelausguß, Scharnierdeckel mit Blattbekrönung, Holzhenkel, Höhe 21 cm, Bruttogewicht 566 gr, Meisterzeichen IN, Stempel für 13-lötiges Silber, Stadtmarke Neustadt (Nagybánya) um 1780.

93 Kapossy i. m. 41.

94 Sotheby's Genf. European Silver. 12th November 1985, 8.: A Parcel-gilt Sweetmeat Dish, maker's mark AW in monogram, town mark crossed mallets, possibly Nagybánya, c.1665, the sides lobed and alternatedly flat chased with baroque flowers, another embossed in the centre, cast S-scroll handles, 130 gr, 13,8 cm wide.

95 Dorotheum 2000. Kunstauktion. Silber (17. Mai 2002.), 69.: Empire Schnupftabakdose. Silber, Innenvergoldung, rechteckig mit abgeschrägten Ecken, Scharnier- deckel, die gesamte Dose mit graviertem Streifen- und Blattdekor, Randzone mit Wellenband, $8,7 \times 4,5 \times 2 \mathrm{~cm}$, Gewicht 130 gr. Meisterzeichen EW, Beschauzeichen Neustadt (?) Anfang 19. Jh.

96 BÁV 23. Müvészeti Aukció (1993. október 20.) 252.: Sótartó. Ezüst, 89,9 gr, belül aranyozott, szárán applikált, koronából kinövő, csavarodó, kígyószerü díszítés. Hitelesítő jegyei szerint a XIX. század elején Nagyváradon készült, mesterjegye szerint Leopoldus Ausländer (?) készítette. Enyhén kopott.

97 BÁV 40. Múvészeti Aukció (2002. április 24.), 512.: Cukorszóró. Ezüst, 203 gr. Kerek talpon tojásdad alakú test, áttört, bajonettzáras tetővel. Jelzett: Nagyvárad, 1810 körül, JS feloldatlan mesterjegy.

98 Kapossy i. m. 45. Monogramja alapján a Várad-Váralján müködött Simon Izsák is szóba jöhetne, de a zsidó származású ötvös valószínűleg nem használt volna koronát a mesterjegyében.

99 Nagyvárad 1828. évi összeírása, MOL Filmtár B50 sz. doboz.

100 Grotte András: Kísérlet néhány magyarországi ötvösjegy feloldására XV. Müvészettörténeti Értesítő 63. 2014 (továbbiakban: Kísérlet XV.), 152. A hiba felismeréséért Fekete Krisztiánnak tartozom köszönettel.

101 Grotte András: Adatok a magyarországi ötvösség történetéhez III. Pápa. Művészettörténeti Értesítő L 2001, 334.

102 Kísérlet XV., 152.

103 Grotte András: Kísérlet néhány magyarországi ötvösjegy feloldására IV. Pécsi ötvösök. Müvészettörténeti Értesítő XLV. 1996, 255.

104 Gál Éva: Egy 19. századi aranyműves mester a források tükrében. X. Kézművesipar-történeti Szimpózium. Budapest, 2001. október 29-30. Harminc év számvetése. Szerk.: Szulovszky János. Budapest 2002, 151-160.

105 Grotte András: Kísérlet néhány magyarországi ötvösjegy feloldására VI. Múvészettörténeti Errtesítő XLVIII. 1999, 130.

106 Kísérlet VIII., 330.

107 Nagyházi Galéria és Aukciósház. 200. jubileumi aukció, a Nagyházi Galéria fennállásának 30. évfordulója (2014. május 29.), 992. sz.: Szelence. Pozsony, 185(?), 13 latos antik ezüst „AS” mesterjegy, belsejében aranyozott, kétosztású ovális, sima test, $98,1 \mathrm{~g}, 6,2 \times 5 \times 2,5 \mathrm{~cm}$.

108 Köszeghy i. m. 303.

109 Mihalik József: Háromszáz év a pozsonyi ötvösség történetéből. Múzeumi és Könyvtári Értesítő V. 1911, 152. 110 Toranová 1982, 236.

111 Grotte András: Kísérlet néhány magyarországi ötvösjegy feloldására V. Müvészettörténeti Értesítő XLVI. 1997 (továbbiakban: Kísérlet V.), 209, 210.

112 Dorotheum 2290. Kunstauktion. Silber (16 Mai 2011.), 560.: Preßburger Zuckerurne. Silber, rund, hochgewölbter Steckdeckel mit floraler Bekrönung, zwei Henkel, Höhe 19 cm, Gewicht 626 g. Meisterzeichen JG=Josef Gerick sen., Preßburger Beschauzeichen 1803.

113 Csók István Antikvitás 90. Árverése (2014. május 26.) 36.: Pozsonyi antik ezüst mokkás kanna . . . 16,5 cm, 302 g. 12 latos antik ezüst, feketére pácolt fafüllel. Jelzett: 12 latos fémjel, AR (?) mesterjegy.

114 Grotte András: Kísérlet néhány magyarországi ötvösjegy feloldására X. Müvészettörténeti Értesítő LIII. 2004, 134 . 
115 Kísérlet VIII., 333.

116 Köszeghy i. m. 298.

117 Toranová 1968, 158. sz.

118 BÁV 58. Müvészeti Aukció (2011. május 26.), 818. sz.: Pozsony-vártelki empire boroskanna. Ezüst, $412 \mathrm{~g}$. Trébelt, ovális talpon amfora alakú edény ívelt füllel. Vállán és billenő fedelén kontúrbeütött és poncolt stilizált növényi díszítmények. Talpán alul jelzett: Pozsony-Vártelek 1813, Fridericus Becker senior. (Kőszeghy K:1817 és 1853 variáns) $M: 23,2 \mathrm{~cm}$.

119 Köszeghy i. m. 331.

120 K:1972/a, Közlemények a Nemzeti Múzeum Érem- és Régiségtárából, I.k. (1916), 65. Ltsz.: 125/914.

$121 \mathrm{~K}: 1972 / \mathrm{b}$

122 Toranová 1982, 152.: Kelch. Johannes Stanga, Schemnitz, 1. Hälfte des 19. Jh. Silber, vergoldet. H: 24,5 $\mathrm{cm}$. Kopie eines Kelches aus dem 18. Jh. Barock gegliederter Fuß mit ziselierten Rocaillen, Blüten, Früchten und Ähren. Der durchbrochene, in Gußtechnik gefertigte Nodus ist mit Weintrauben, Ähren und Rosen geschmückt. Auf der Kuppa des Kelches ist eine Berglandschaft mit Bergleuten bei der Arbeit ziseliert.

123 Óra- és Ékszerkereskedelmi Vállalat 1986. Őszi Ékszer- és Nemesfém-aukció (1986. november 25.), 209. sz.: Evőkanál, hat db. Antik ezüst, előrehajló lándzsalevélvégü nyéllel, vésett $\mathrm{AH}$ monogrammal, Selmecbánya 1840 körül, Stanga János, súly 383 g.

124 Kószeghy i. m. 331.

125 Toranová 1968, 166, 202. Banská Stiavnica, Slovenské banské múzeum, leltári szám nélkül, ill. Bratislava, Slovenské narodné múzeum, Inv. č. UH 4166.

126 Toranová 1968, 195-196. Bratislava, Slovenské národné múzeum. Inv. č. UM 3474-3475.

127 Köszeghy i. m. 331.

128 Toranová 1968, 192. A filigrángomb átmérője 3,8 $\mathrm{cm}$. Bratislava, Slovenské národné múzeum, Inv. č. UH 1172 .

129 BÁV 25. Müvészeti aukció (1994. október 25.), 92. sz.: Mentegomb (5 db). Antik ezüstfiligrán, kúpos forma, csúcsán kettős rozettán kis gúla. Selmecbánya 1850 körül, Szladek készítő jegy, súly 38,9 g, jó állapotban.

130 Pless és Fox Ékszerüzlete. 94. Árverés. 1997. november 24., 8. sz.: Antik karkötő, filigránezüst. Selmec- bánya 19. sz. közepe. Szladek (K:1976) és 13 (K:1949 vagy 1950). Ugyanezt a 95. Árverésen 1997. december 15-én újra árverezték.

131 BÁV 66. Ékszeraukció (2003. december 9.), 695. sz.: Díszgomb. Ezüstfiligrán, 11 g. Jelzett: Selmecbánya, 1860 körül, Szladek mesterjegy, K:1976.

132 Toranová 1968, 199. A filigrángomb átmérője 3,2 cm. Bratislava, Slovenské národné múzeum, Inv. č. UH 3418.

133 Mihalik József: Adalékok a besztercebányai ötvösökhöz. Múzeumi és Könyvtári Értesítő VII. 1913, 237. Uô: Besztercebányai ötvösök a XV-XIX. században. Múzeumi és Könyvtári Értesítő XII. 1918, 135. (Továbbiakban: Mihalik 1918.)

134 Köszeghy i. m. 331, Mihalik József: Régi hazai ötvösmüveink az ezredéves országos kiállításon. Archeológiai Értesítő, Új Folyam XVI, 1896, 331.

135 Toranová 1968, 151 sz. (Inv. č. 533), 175 sz. (Inv. č. 3499), 182 sz. (Inv. č. UH 3554).

136 Heller i. m. (33. j.) 128. sz.

137 Polgár Galéria és Árverezőház. 79. Karácsonyi Müvészeti Aukció (2008. december 3.), 456.: Hatszemélyes antik teáskanálkészlet. 13 latos antik ezüst, $126 \mathrm{~g}$, 15,5 cm. Jelzett: Selmecbánya 1840 körül, Trauer (Jacobus Trauer, mük.: 1840-1856) mesterjegy.

138 Mihalik 1918, 142.

139 Köszeghy i. m. 331: Trauer selmecbányai működési idejére 1840-1857 időintervallumot ad meg. A Toranovánál (Toranová 1982, 233) szereplő 1867 valószínűleg nyomdahiba.

140 Kapossy i. m. 46. Az 1828-as összeírás (MOL Filmtár B245 sz. doboz) szegénynek (miser) nevezi, aki legény nélkül dolgozik fél éven át.

141 Kísérlet V., 215.

142 Kapossy i. m. 34. Az 1828-as összeírás (MOL Filmtár B245 sz. doboz) szerint egyedül dolgozik fél éven át.

143 Köszeghy i. m. 279.

144 MOL Filmtár A3582-3584 sz. dobozok. Az 18021895 között vezetett születési anyakönyv 1802-1851 között héber nyelvü, ezt nem tudtam használni, 1851-1885 között pedig a szülők foglalkozását nem tüntették fel. A házassági és a halálozási anyakönyveket csak 18511895 között vezették.

\section{ATTEMPTING TO RESOLVE SOME HUNGARIAN GOLDSMITH'S MARKS XVI.}

Going on with a series of articles, I present again some so-far unknown maker's marks and mark variants in private collections and the art trade, and try to identify them. When already published marks are at issue, Elemér Köszeghy's book of marks is referred to, and Ilona P. Brestyánszky's work is mentioned with the mark's serial number there when marks of Pest-Buda are discussed. I try to clarify the biography of goldsmiths active in Hungarian towns on the basis of archival research, first of all with parish register data. In the appendix I give a list of gold- and silversmiths named in the registers of the Israelite community of Óbuda between 1851 and 1895, and those in the census of 1850 .

\section{GROTTE András H-1145 Budapest, Columbus u. 32.}

Kulcsszavak: ötvösség, 19. század, ezüst, ötvösjegyek, anyakönyvi adatok, Pest, Óbuda, Késmárk, Kolozsvár, Nagybánya, Nagyvárad, Pápa, Pozsony, Selmecbánya, Újvidék / Keywords: goldsmithing, 19th century, silver, master's mark, matricula data, Pest, Óbuda, Kežmarok, Cluj-Napoca, Bia Mare, Oradea, Pápa, Bratislava, Banská Stiavnica, Novi Sad 